\title{
ASSESSMENT OF GEOTHERMAL ENERGY RESOURCES
}

Federal Council for Science and Technology

JUNE 1972

Distributed By:

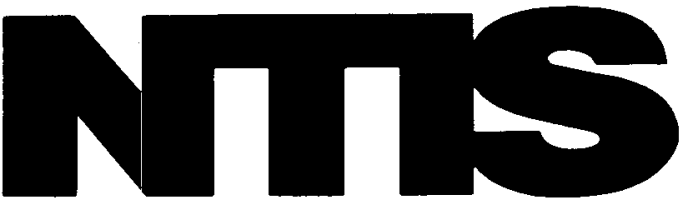

National Technical Information Service

U. S. DEPARTMENT OF COMMERCE 


\section{DISCLAIMER}

This report was prepared as an account of work sponsored by an agency of the United States Government. Neither the United States Government nor any agency Thereof, nor any of their employees, makes any warranty, express or implied, or assumes any legal liability or responsibility for the accuracy, completeness, or usefulness of any information, apparatus, product, or process disclosed, or represents that its use would not infringe privately owned rights. Reference herein to any specific commercial product, process, or service by trade name, trademark, manufacturer, or otherwise does not necessarily constitute or imply its endorsement, recommendation, or favoring by the United States Government or any agency thereof. The views and opinions of authors expressed herein do not necessarily state or reflect those of the United States Government or any agency thereof. 


\section{DISCLAIMER}

Portions of this document may be illegible in electronic image products. Images are produced from the best available original document. 
ASSESSMENT OF GEOTHERMAL ENERGY RESOURCES

Prepared for the

Committee on Energy Research and Development Goals

Federal Council of Science and Technology

June 26, 1972

Panel on Geothermal Energy Resources

Daj1as L. Peck, Coordinator

Department of the Interior 
1. CONCLUSTONS AND RECOMMPNMATIONS $\ldots \ldots \ldots \ldots \ldots \ldots \ldots \ldots \ldots \ldots \ldots \ldots \ldots \ldots \ldots$

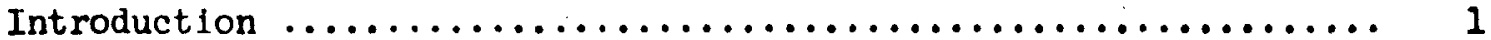

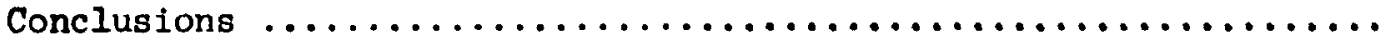

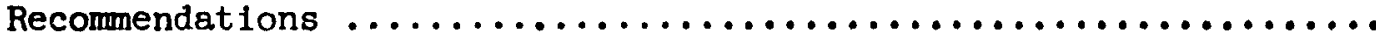

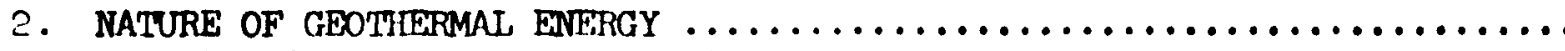

Locel Geothermal Reservolrs ........................ 13

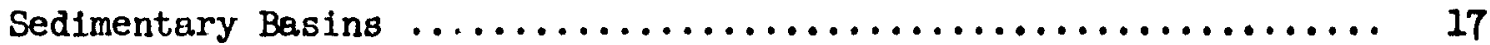

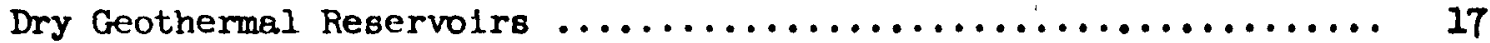

3. CURREVT UTILIZATION $\ldots \ldots \ldots \ldots \ldots \ldots \ldots \ldots \ldots \ldots \ldots \ldots \ldots \ldots \ldots \ldots \ldots \ldots \ldots \ldots . \ldots \ldots$

4. CURREMT RESEARCH AND DEVETOPAENT $\ldots \ldots \ldots \ldots \ldots \ldots \ldots \ldots \ldots \ldots \ldots \ldots \ldots \ldots \ldots \ldots$

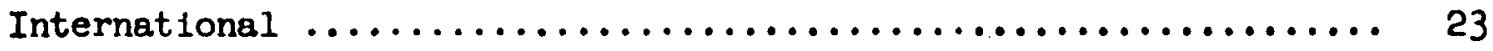

Untted States of America $\ldots \ldots \ldots \ldots \ldots \ldots \ldots \ldots \ldots \ldots \ldots \ldots \ldots \ldots \ldots \ldots \ldots$

U.S. Geological Survey ......................... 26

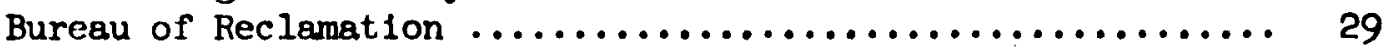

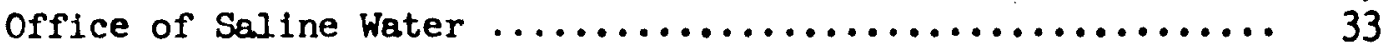

Bureau of Mines .............................. 35

Bureau of Iand Management ........................ 37

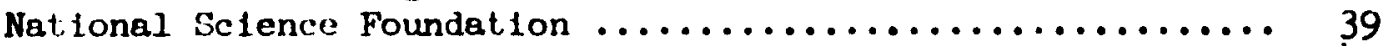

Atomic Energy Commission ....................... 42

Department of Defense, Advanced Research Projects Agency .... 45

National Aeronautics and Space Administration ............ 46

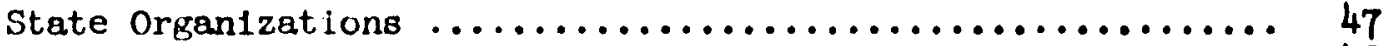

Private Industry ............................. 48

Relevant Research directed at other Energy Resources ....... 50

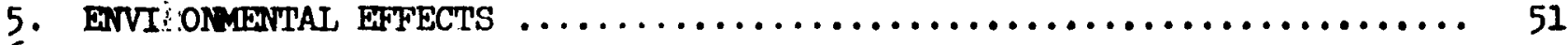

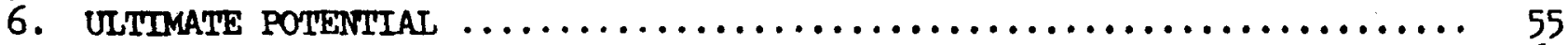

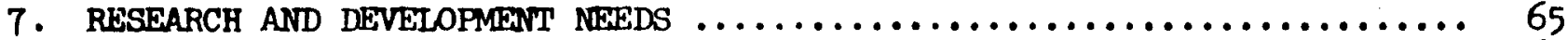

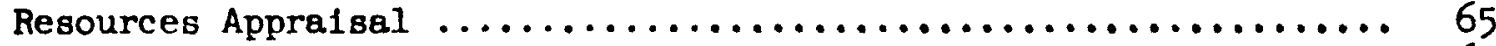

Exploration Methods ............................... 67

Reservoir Development and Production ..................... 69

Ut1lization Technology and Economics ................... 72

Envi ronmental Effects ............................. 74

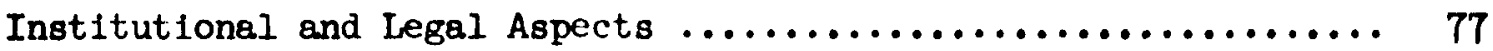

8. REAFGRENCES ...................................... 79

\section{TABIES}

1. World Geothermal Power Production, $1972 \ldots \ldots \ldots \ldots \ldots \ldots \ldots \ldots \ldots \ldots \ldots \ldots$

2. Three Recent Sets of Geothermal Resource Estimates .............. 58

\section{FIGURES}

1. Hot springs, known geothermal areas, and producing geothermal

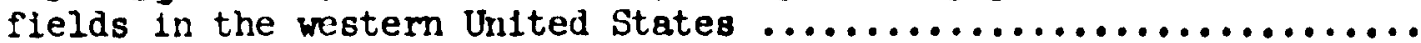

2. Estimated reserves and resources of geothermal energy ............ 56 
ASSL'SIMENT OF GFXIHLIMAL ENERGY RESOURCES

CHAPTER 1

CONCLUSIONS AND RECOMMENDATIONS

\section{Introluction}

The Office of Science and Technology, in cooperation with the Federal Council on Science and Technology and appropriate Federal agencles, is carrying out an extensive assessment of energy technologies in response to a request from the President in his message on energy of June 4, 1971 . As part of this endeavor, the Office of Sclence and Technology in December 1971 requested the Department of the Interior to assess the technology of geothermal energy and recommend a program of research and development. The assessment has been carried out by the U.S. Geological Survey in collaboration with two panels of experts. The first, an informal interagency geothermal coordinating comittee, which began meeting in September 1971 to promote communication between Federal agencies involved in the geothermal resources field. Members of the following agencies have participated in the meetings held at least once a month since the comittee was established: Bureau of Reclamation, Offlce of Saline Water, Geological Survey, Bureau of Mines, National Science Foundation, Atomic Energy Commission, National Aeronautics and Space Administration, Advanced Research Projects Agency, Bureau of Land Management, and Environmental Protection Agency. The members of this committee contributed to this report and reviewed its conclusions. The second panel of experts was established in May 1972, when the National Sclence Foundation, RANN Program, approved a research proposal submitted by Walter J. Hickel, Adjunct Professor of the University of Alaska and former Secretary of the Interior, to hold a conference on geothermal resources 
research in order "To develop an assessment of the state of the art and 10 reommend 1 resemph prowram to provlde the requlalte knowledge for establishing, the proper role of geothermal resources in providing

(1) additional energy to alleviate the Nation's impending shortage, (2) weter to supplement present supplies, and (3) mineral resources." The conference is planned for september 1972 and will include about 60 knowledgeable scientists, engineers, and other experts from industry, universities, and state and Federal afencles. The attendees will be divided into stx sub-panels as follows: (1) Resources Evaluation, (2) Resource Exploration, (3) Feservoir Developnent and Production, (4) Ut: 17 i:iation - Technolopv and Economics, (5) Envlronmental Effects, and (6) Tnstitutional Froblens. The final report from this conference will provide an expanded and detalled list of recommended research and development topics that should pruvide a useful supplement to this present report. The co-chairman of the siat-panels, $1 /$ all of whom are from industry, universities, and state agencies, met with the principal investigator, Mr. Hickel, and the executive secretary, Dr. Dunlop, in Anchorage, Alaska, on May $\gamma$ and 9, 1972. At this neting they planned the September conference and mad preliminary rocommendetions for research end development that provide a majcr part of the recomendations of this report. 1/ Official attendees at the May 8 and 9,1972 , conference were as follows: 
Mr. Walter J. Hickel

Principal Investigator

Dr. Donald D. Dunlop

Executive Secretary

Prof. L. 'T. Grose

Co-chai mnan, Resources

Evaluation Sub-panel

Prof. Robert W. Rex

Co-chairman, Hesources

Evaluation Sub-panel

Prof. Gunnar Bodvarsson

Co-chairman, Resource

Exploration Sub-panel

Mr. Dunald H. Stewart

Co-chalrman, Reservoir

Development and Production

sub-janel

$\mathrm{Mr}$. Herbert Rogers, Jr. Co-chairman, Utilization Technology and Economics sub-panel

Mr. John P. Finney

Co-chairman, Utilization Technology and Economics Sub-panel

Prof. Hamilton Hess

Co-chairman, Envi ronmental

Effects Sub-panel

$\mathrm{Mr}$. Richerd Bowen

Co-chaiman, Environmental Ef'fects Sub-panel

Mr. Joseph W. Aidlin

Co-chairman, Institutional

Problems Sub-panel.

$\mathrm{Mr}$. Stewart French

Co-chai nman, Institiutional

Problems Sub-panel

Dr. Jesse C. Inenton

Observer

Dr. Dallas L. I'eck

Observer
Adjunct Professor

UnI versity of Alaska

Falrfax, Virginia o

Colorado School of Mines

University of Callfornia, Riverside

Oregon State UnIversity

Battelle Northwest

Rogers Engineering Company, Inc.

Pacific Gas and Electric Company

University of Sen Francisco

Oregon Department of Geology and

Mineral Industries

General Counc11, Magma Power Company

Private Law Practice, Washington, D. C . (former Chlef Council, Senate Interior Committee)

National Science Foundation

U.S. Geological Survey 
Other contributors to and reviewers of this report not present at the Anchorage conference were:

Dr. Abraham E. Dukler

Dr. Carel otte

Dr. H. J. Ramey, Jr.

Dr. Ceoffrey R. Robson

Dr. Bernardo Grossling

Dr. L. J. P. Muffler

Dr. Donsld E. White
University of Houston

Union 011 Company of California

Stanford University

UnIted Nat1ons, New York

U.S. Geological Survey

U.S. Geological Survey

U.S. Geological Survey

\section{Conclusions:}

Geothermal resources are a natural source of relatively clean energy, water, and minerals that could have a significant impact in the United States if developed to its full potential. In particular, geothermal steam and hot water could provide a signiflcant part of the Nation's electrical energy needs within the next few decades, especially in the western states, Hawa11, and Alaska. Estimates by knowledgeable experts of the impact of geothermal resources on the Nation's energy needs differ, but it appears that at least $19,000 \mathrm{Mw}$ of generating capacity could be installed by 1985 using technology presently available or under development, and that more than 75,000 Mw could probably be installed by the year 2000 granted a successful expanded Federal research and development program. A much greater potential exists in the large submarginal resources of hot fluids and rocks that occur beneath the surface of the United States, but their conmercial development must await technological breakthroughs. Geothermal resources also have a 
significant potential for direct use in industrial processes, space heating, africulture, refrigeration, the production of fresh water by desalination, and the production of mineral byproducts.

Recommendations:

An expanded ;-year Federal program is needed to assess the magnitude, type, and location of the Nation's geothermal resources and to spur the development of improved technology for discovering, evaluating, and utilizing the resource. Fundine needed for the first year of the program, including existing funding, is estimated to be $\$ 25,000,000$. Of this total, approximately one third would be directed toward research and development directly applicable not only to geothermal energy but also to other energy sources, particularly the development of better techniques for drilling, borehole logging, power generation, desalting, scale removal, alr pollution, and noise reduction. In comparison, funds for research and development in fiscal year 1973, in identified geothermal programs of Federal agencies as requested in the President's budget, total about $\$ 6,385,000$. An additional $\$ 475,000$ has been requested for the management of the geothermal resources of the public lands. Possible supplementary funding for geothermal programs of the Atomic Energy Commission and other agencles may raise the total funds for Federal geothermal programs in FY 73 to the level of $\$ 10,000,000$. 
Recommended funding levels for a proposed 5-year program are listed below:

Proposed 5-year Geothermal Research and Development Program

\begin{tabular}{|c|c|c|c|c|c|c|}
\hline & FY-74 & FY-75 & FY-76 & FY-TT & FY -78 & Total \\
\hline Resource Appraisel & $\$ 6 \mathrm{M}$ & $\$ 9 \mathrm{M}$ & $\$ 15 \mathrm{M}$ & $\$ 10 \mathrm{M}$ & $\$ 6 \mathrm{M}$ & $\$ 46 \mathrm{M}$ \\
\hline Exploration Methods & $5 \mathrm{M}$ & $9 \mathrm{M}$ & $9 \mathrm{M}$ & $5 \mathrm{M}$ & $3 \mathrm{M}$ & $31 \mathrm{M}$ \\
\hline $\begin{array}{l}\text { Reservoir Development } \\
\text { and Production }\end{array}$ & $5 \mathrm{M}$ & $9 \mathrm{M}$ & $13 \mathrm{M}$ & $22 \mathrm{M}$ & $17 \mathrm{M}$ & $66 \mathrm{M}$ \\
\hline $\begin{array}{l}\text { Ut1lization Technology } \\
\text { and Economics }\end{array}$ & $6 \mathrm{M}$ & $8 \mathrm{M}$ & $9 \mathrm{M}$ & $11 \mathrm{M}$ & $16 \mathrm{M}$ & $50 \mathrm{M}$ \\
\hline Environmental Effects & $1.5 \mathrm{M}$ & $3 \mathrm{M}$ & $1.5 \mathrm{M}$ & $I M$ & $1 \mathrm{M}$ & $8 \mathrm{M}$ \\
\hline \multirow[t]{2}{*}{$\begin{array}{l}\text { Institutional and Legal } \\
\text { nspect,s }\end{array}$} & $1.5 \mathrm{M}$ & ? $\mathrm{M}$ & $1.5 \mathrm{M}$ & $1.5 \mathrm{M}$ & $1.5 \mathrm{M}$ & $8 \mathrm{~m}$ \\
\hline & $\$ 25 \mathrm{M}$ & $\$ 40 \mathrm{M}$ & $\$ 49 M$ & $\$ 50.5 \mathrm{M}$ & $\$ 44.5 \mathrm{M}$ & $\$ 209 \mathrm{M}$ \\
\hline
\end{tabular}


The proposed 5-year program should result in a number of significant accompli: huments, including the following: (1) better knowledge of the nature, magnitude, quality, and location of geothermal resources; (2) better exploration techniques including cheaper drilling technology; (3) reduced costs and time for developing geothermal flelds; (4) longer Iffe for fields through recharge methods; (5) determination of the feasibility of stimulating geothermal reservolrs and of recovering thermal energy from hot, relatively dry rocks; (6) improved power-generation technology for use of intermediate- and low-temperature geothermal waters and concentrated brines; (7) technology for desalting geothermal brines; (8) determination of the feasibility of recovering chemicals from geothermal fluids; (9) monitoring of environmental effects of all geothermal developments; (10) 1mproved techniques for removing $\mathrm{H}_{2} \mathrm{~S}$ from geothermal steam and for reducing nolse from drilling; (11) preparation of a model code for geothermal development; (12) better liaison and distribution of geothermal information between Federal, State; and local agencles, the academic community, and the geothermal industry; and (13) establishment of several national geothermal field research laboratories. During the 5-year program, the design, construction, and operation of several pllot. plants will have demonstrated the technologies for power conversion and brine desalting so that design and construction of large scale demonstration plants can proceed.

Research and development needs are ilsted in the sections below not by priority but rather by broad toplcal areas following the organization of the Geothermal Resources Research Conference. Funding levels for the different 
toplenl arens are recommended only for the lirst year of the program. As the program develops, funding levels should shift to reflect research and development needs. From the beginning the progrem should include both activities with short range goals and others with longer range goals. However, several elements of the program need to be pursued at an adequate level early in the program in order to better define the magnitude of the resource and spur its development. These high priority elements include (1) development of improved exploration methods, (2) development of better power-generating technology including binary-fluld systems, (3) development of improved drilling techniques and the drilling of many shallow and deep bore holes, (4) development of better models of geothermal reservolrs by computer simulation, (5) development of improved economic models of geothermal utilization from different types of reservolrs using different power generation techniques, and (6) development of desalination methods for geothermal fluids.

Resources Appraisal:

Better estimates of the magnitude, quality, and distribution of the geothermal resources of the United States are needed to develop Federal strategy for meeting future energy needs and for the management of the geothermal resources of the public lands. An expanded Federal program of regional reconinalssance, heat flow measurements, and research drilling to depths as great as $3 \mathrm{~km}$ is recommended for the definition of the geothermal provinces of the United States, the assessment of their potential, and the identification and evaluation of promising areas. Drilling funded under this 
program ls essential to it.s mucess a:s well as to the success of the programs

i on Exploration Methods and Reservolr Development and Production. Funding needed for the first year is estimated to be $\$ 6,000,000$. A program of very deep drilling (to $6 \mathrm{~km}$ ), although not recommended at this time is essential to determining the thermal potential of the deep crust beneath the United States.

Exploration Methods:

Development of geothermal resources 18 handicapped by insufficient understanding of geothermal reservoirs and relatively primitive exploration techniques. An expanded Federal program is needed (1) to develop better geophysical and other methods of exploration, (2) to develop faster, cheaper drilling techniques for drilling both deep and ohallow holes by improvement of existing techniques and development of new methods, and (3) to develop improved techniques for logging wells and sampling fluids from them at the high temperatures involved. Funding needed for the first year is estinated to be $\$ 5,000,000$.

Rescrvoir Development and Production:

An expanded Federal program is needed to reduce the time and costs of developing geothermal flelds, to solve problems in producing and reinjecting geothermal f'luids, to extend the life of fields, and to enlarge the resource $V$ by tapping the heat stored in hot, dry rocks. The program would include the following elements: (1) modeling geothermal reservoirs by computer simulation; (2) investigation of recharge methods; (3) research on the geochemistry of geothermal fluids; (4) development of techniques for detecting and removing scale and preventing its formation; (j) investigation of artificial stimulation 
of geothermal reservoirs by hydraulic fracturing, thermal stress fracturing, and fracturing by explosives; and (6) study of the feasibility and economics of recovering heat from hot, relatively dry rock masses by fracturing and introduction of water. Funding needed for the first year is estimated to be $\$ 5,000,000$.

\section{Ut1l1zation Technology and Economics:}

Improvements in utilization technology of geothermal fluids could greatly expand the recoverable resource, particularly (1) power generation techniques using geothermal waters of intermediate temperatures $\left(<180^{\circ} \mathrm{C}\right.$, $356^{\circ} \mathrm{F}$ ) or with abundant dissolved salts, and (2) multiple use of the resource. An expanded Federal program is needed (1) to conduct research and demonstration programs on techniques of electrical power production using a variety of power cycles including binary-fluid conversion systems; (2) to develop and demonstrate the technology for desalting geothermal brines, and (3) to conduct research and development on the recovery of minerals and gases from geothermal fluids. A.ll these elements, as well as the development of better drilling and borehole logging technology, will require development of improved heat and corrosion resistant materials, and should be accompanied by economic analysis of geothermal utilization of different types of flelds using different technology. Funding needed for the first year is estimated to be $\$ 6,000,000$.

\section{Environmental Effects:}

An expanded Federal program is needed to assure that geothermal development is accomplished in an environmentally sound manner. The program should include monitoring of environmental effects of geothermal developments, including 
where relevant, quality of surface water and ground water, land oubsidence, and selomic activity. Research and development under the program would be focused on improving technlques for removing $\mathrm{H}_{2} \mathrm{~S}$ and other toxic gases from geothermal steam and for reducing the nolse from drilling, well cleanout, and well bleeding. Funding needed for the first year 18 estimated to be $\$ 1,500,000$.

Institutional and Legal Aspects:

An expanded Federal program is needed: (1) to manage the geothermal resources of the public lands; (2) to investigate several legel aspects of geothermal developments, including the preparation of a model code, (3) to establish and maintain better liaison between Federal, State, and local agencies, the academic conmunity, and the geothermal industry, (4) to ald local agencies in the preparation of plans for the orderly development of local seothermal resources, (s) to establish a central Federal fac1lity for gathering and distributing information on geothermal resources, and (6) to evaluate the need for geothe mal field research laboratories. Funding needed for FY 1974 is estimated to be $\$ 1,500,000$, of wh1ch $\$ 1,000,000$ would be directed toward management of the public lands. 
CHAPTER ?

NATURE OF GEOTHTIUMAL EANEROY

Ceothermal energy is, in the broadest sense, the natural heat of the earth. Measurements in wells and mines demonstrate that temperatures overall increase with depth, and generally accepted views about the composition of the earth indicate that temperatures continue to rise to $200^{\circ} \mathrm{C}$ to $1000^{\circ} \mathrm{C}\left(392^{\circ} \mathrm{F}\right.$ to $\left.1832^{\circ} \mathrm{F}\right)$ at the base of the continental crust (a depth of 25 to $50 \mathrm{~km})$ and to perhaps $3500^{\circ} \mathrm{C}$ to $4500^{\circ} \mathrm{C}\left(6332^{\circ} \mathrm{F}\right.$ to $\left.8132^{\circ} \mathrm{F}\right)$ at the center of the earth. Most of the heat stored in the earth 18 at too great a depth or too diffuse to be considered as a potential resource with technology of the near future. However, economically significant concentrations of geothermal energy are present in several different types of occurrences. Elevated temperatures $\left(40^{\circ} \mathrm{C}\right.$ to $380^{\circ} \mathrm{C}, 104^{\circ} \mathrm{F}$ to $\left.716^{\circ} \mathrm{F}\right)$ are found in local "hot spots" in permeable rocks at shallow depths (less than $3 \mathrm{~km}$ ). The thermal energy $1 \mathrm{~s}$ stored both in solid rock and in water and steam filling pores and fractures, and the water and steam serve to transfer the heat from the rock to $a$ well and thence to the ground surface. Almost all the presently utilized geothermal systems are of this type. Geothermal reservoirs that contain too little moblle fluid because of impermeable reservoir rocks are not economic reservoirs at the present time, even though they may be of sufficiently high temperature. If sultable technology is developed to tap these reservoirs, they may in the future const1tute a very large resource. Another type of geothermal resource is the heat contalned in hot interstitial waters in sedimentary basins such as the Gulf Coast geosyncline (Jones, 1970). The magnitude of the heat stored in sedimentary basins in the United States is large, but as yet the resource remains untapped. 
Local Geothermal Reservolrs:

Local geothermal reservolrs occur in the upflowing parts of major water convection systems. Water serves as the medlum by whlch heat is transferred from a deep source, presumably a molten lgneous intrusion, to a geothermal reservoir at depths shallow enough to be tapped by drill holes. Water percolating underground from an area of tens to thousands of square kilometers is heated by contact with hot rock at depths of 2 to $6 \mathrm{~km}$, expands upon heating, and moves buoyantly upward in a thin column of relatively restricted cross-sectional area (1-50 $\left.\mathrm{km}^{2}\right)$ (White, 1968; Muffler and White, 1972). If the rocks have a high permeability, the heated water rises rapidly to the surface and is dissipated. If, hovever, the upward movement is impeded by overlying rocks of low permeability, the geothermal energy may be stored in a reservoir beneath the cap.

The fluid in most geothermal systems is water, which may be at temperatures above surface bolling but in a liquid state because of the confining pressure. The water in most of these "hot-water" or "wet-steam" geothermal systems is a dilute sclution containing mostly sodium, potassium, chloride, bicarbonate, sulfate, borate, and silica. The silica content and the ratio of potassium to sodium and calcium are dependent on the temperature In the geothermal reservoir, thus the prediction of subsurface temperature from chemical analysis of hot springs is possible (Fournier and Rowe, 1966; Ellis, 1970). Decrease in pressure upon withdrawal of the water to the surface through a well or natural fracture causes stean to be formed by bolling and a mixture of steam and water is produced at the surface. W1th present technology only the steam can be used to generate electricity. 
The major known hot-water geothermal flelds are Walrakel and Broadlands in New Zealand, Cerro Prieto in Mexico, the Salton Sea fleld in California, and the Yellowstone geyser basing in Wyoming:

A small proportion of the known local geothermal systems produces superheated steam with minor amounts of other gases $\left(\mathrm{CO}_{2}, \mathrm{H}_{2} \mathrm{~S}, \mathrm{NH}_{3}\right)$, but little or no water. Thus all the fluld from these "vapor-dominated" or "dry-steam" geothermal systems can be piped directly to the turbine. Within the vapor-dominated reservolr, saturated steam and water co-exist, but with decrease: in pressure upon production, heat contalned in the rocks dries the fluid first to saturated steam and then to steam with as much as $55^{\circ} \mathrm{C}$ superheat. Hot brines probably exist below vapor-dominated reservolrs (James, 1968), but bore holes have not been drilled deep enough to confirm their presence. Larderello, Italy; The Geysers, California; and Matsukawa, Japan, are the major known vapor-dominated systems.

Local geothermal reservolrs are found in regions of the world where the flow of heat from depth in the earth is $1 \frac{1}{2}$ to 5 times greater than the world-wide average of $1.5 \times 10^{-6}$ calories per square cm per second. Such regions of high heat flow commonly are zones of young volcanism, igneous Intrusion, and mountain building, and most are located along the margins of the major crustal plates of the earth. Geothermal flelds are absent from the stable continental shields, which are characterized by lower-thanaverage heat flow. Local geothermal reservoirs have not been found at shallow depth in the non-volcanic continental areas bordering the shields, but hot water has been found to occur as interstitial fluids in sedimentary 
basins at greater depth $(3$ to $6 \mathrm{~km})$. In the United States the diatribution, extent, and megnitude of geothermal reservolrs are, at present, poorly known. The general extent of the resource can be inferred from distribution of hot springs ( $\mathrm{flg} .1$; from Waring, 1965), and in a more general way from the distribution of young volcantc rocks and areas of high heat flow. The potential within the United States involves primarily the western states, particularly California, Nevada, Oregon, southern Idaho, Utah, New Mexico, Wyoming, Arizona, Colorado, Hawail and Alaska. In the past, geothermal exploration has been primarily on sites identified by hot springs, an exploration method analogous to the primitive oll exploration methods of the previous century when ofl fields could be located only by finding surface ofl seeps. Available geologic and geochemical techniques have not been used adequately in discovering and evaluating new flelds, and geophysical principles and techniques are only now beginning to be adapted to geothermal exploration.

Knowledge of the character and parameters of individual geothermal systems has come from exploratory drilling, from limited developmental drilling (mainly at The Geysers of northern California and at the Salton Sea, in southern California), and from limited studies of major thermal-spring areas, supplemented by shallow research drilling. Extrapolation of knowledge from other countries, mainly New Zeeland, has proved useful, but techniques for estimating the size and power potential of geothermal sites prior to drilling are only beginning to be developed. 


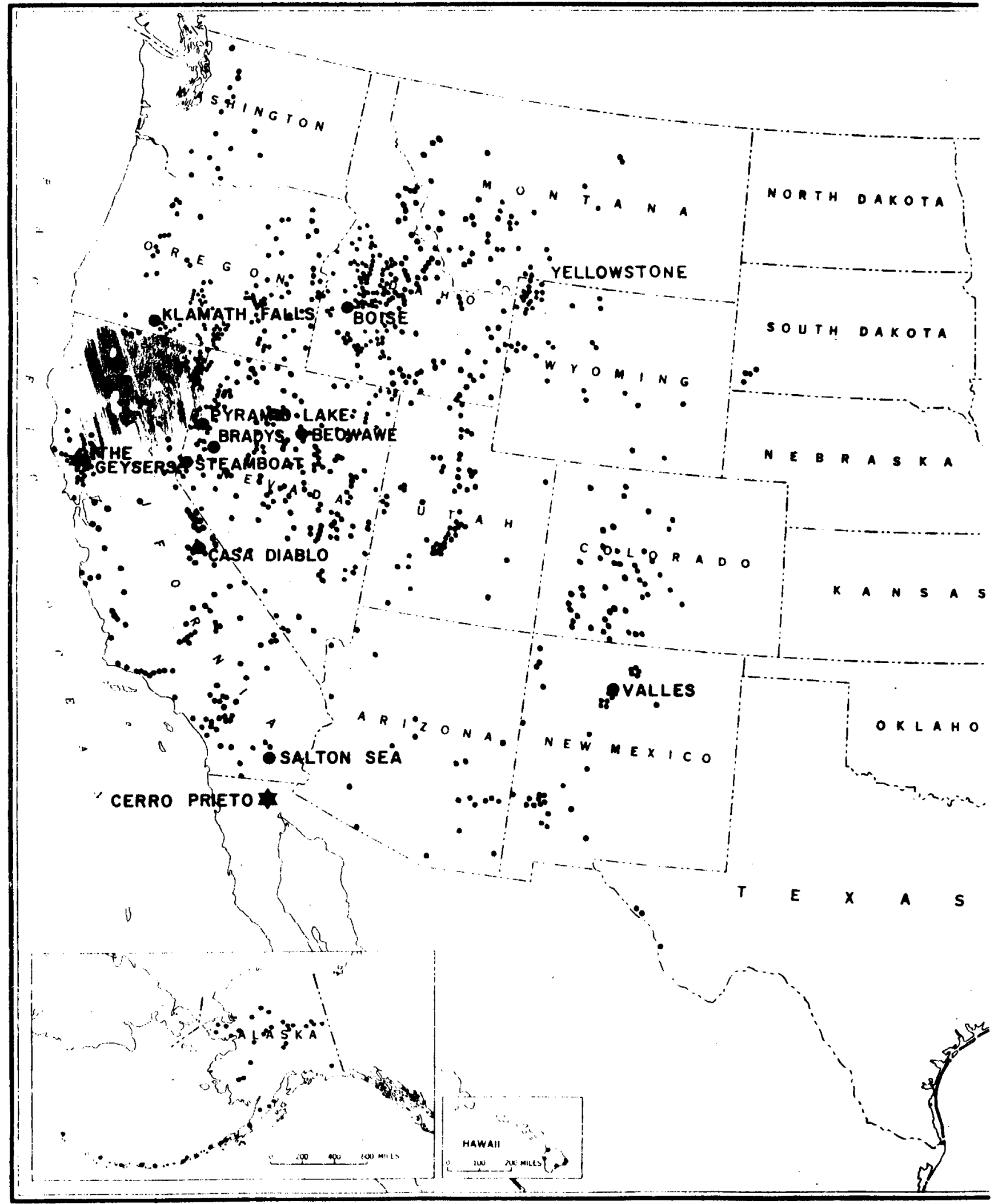

Figure 1. Hot. Sprinfs (sumbl dots), known poothermal areas (large dots), and producing geothermal fields (star), in the western United States (from Waring, 1965). 
Sedimentary Basins:

Hot interstitial waters in deep uedimentury basino of normal or slightly greater than normal geothermal sradients ropresent a large geothermal potential. In Hungary $15 \times 10^{83} \mathrm{Btu} / \mathrm{hour}$ of thermal energy in hot water is being produced from 80 wells and used mainly for space heating (Boldiszar, 1970). In the Gulf Coast area, hot over-pressured water is present at depth beneath large areas (Jones, 1970). Many thousands of wells there now produce fluid hydrocarbons and water at temperatures far above the bolling point of water at atmospheric pressure. Many test wells have produced water-steam mixtures, some ylelding more than a million barrels of brine hot enough to be self distilling. Lower-temperature interstitial waters at shallower depths in sedimentary basins contain an even larger amount of heat (Grossling, 1972), but are far less attractive economically. Dry Ceothermal heservoirs:

Under present technology, a rock mass with too few pores or fractures, or with pores that are not interconnected, does not comprise an economic reservoir, however hot it may be. The abundance of hot but relatively dry geothermal reservoirs is not known but may be very large. If the technology could be developed to economically recover thermal energy from such reservolrs by artificial formation of fractures and by the introduction of fluids if necessary, the magnitude of geothermal resources could be greatly increased: Furthermore, if drilling technology is also improved significantly, the technology for tapping the thermal. ener could concelvably be applied in arias of normal heat flow, thus introducing the possibility of tapping the enormous geothermal resource base of the earth's crust. 
The primary use of geothermal resources to date is for the generation of electricily. For this purpose, under exlsting, technology, the geothermal reservoir must have a temperatiure of at least $180^{\circ} \mathrm{C}\left(356^{\circ} \mathrm{F}\right)$, and preferably $200^{\circ} \mathrm{C}\left(392^{\circ} \mathrm{F}\right)$, and lie at shallow enough depths ( $3 \mathrm{~km}$ or less) to be developed economically. In "dry-steam" flelds, the steam is fed directly from well-head to turbine after removal of abrasive particles. In "wet-steam" fields, on the other hand, bolling of hot water at depth yields a mixture of steam and water at the surface. Water at $250^{\circ} \mathrm{C}\left(482^{\circ} \mathrm{F}\right)$ w1ll produce only about 20 weight percent steam when the confining pressure is reduced to $6 \mathrm{Kg}$ per square $\mathrm{cm}$, the approximate well-head pressure in geothermal installations. The steam and weter are mechanically separated at the wellhead and the steam fed to a turbine. In both types of fields the steam is et a much lower pressure compared to that used in fossil fuel or nuclearpowered generating plants, so that specially designed turbines are used in geothermal plants to drive the conventional generators. World electrical capacity from geothermal energy in 1971 was approximately 800 megawatts (table 1), or about 0.08 percent of the total world electrical capacity from

all generating modes. The production of geothermal power is obviously restricted to areas where geothermal energy is found in sufficient quantity. Unlike coal, oll, gas, or uranium, geothermal steam cannot be transported long distances to an electric power generating plant located near the existing load centers. 
Table 1

World Geothermnl Power Capac1ty 197?

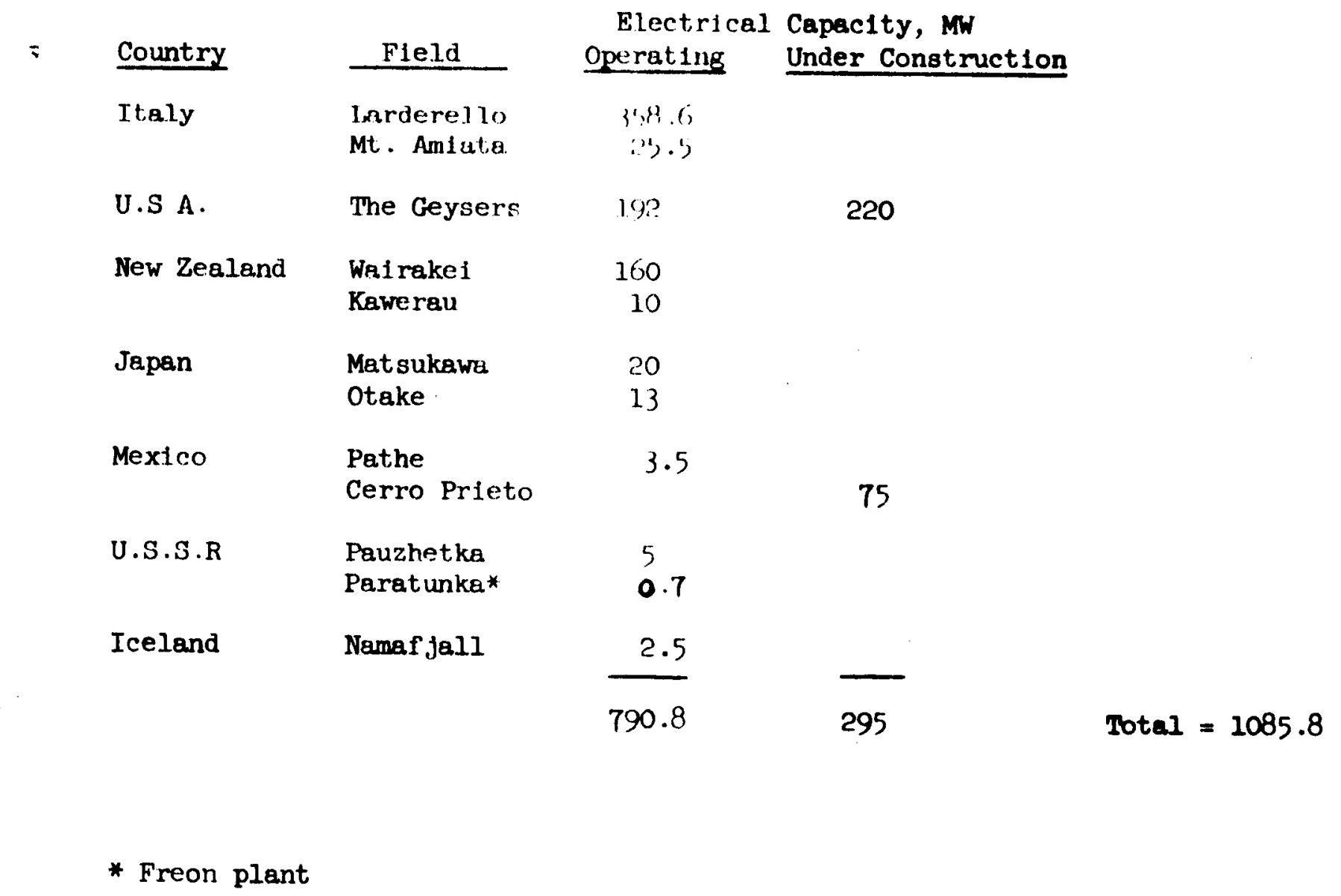

Total $=1085.8$ 
Power from favoratle geothermal systems is competitive in cost whth either fossil-fuel or nuclear power. The current unit cost of developing geothermal production from dry-steam flelds in the United States based on experience at The Geysers and using a load factor of 85 percent (U.S. Energy Outlook, 1972), is about 0.525 per $k$ wh. Th1s cost can be broken down into 2.66 mills for the steam delivered to the plant, $0.45 \mathrm{mills}$ for operating costs, and $2.14 \mathrm{mills}$ for capital costs. Such costs are cheaper than power from fossil-fuel steam plants and current nuclear plants. The cost of generating power from the more abundant hot-water reservolrs should be somewhat greater because of the more complex equipment 1nvolved, and higher reinjection costs if brine reinjection is required.

With present technology, geothermal stean 18 separated from entrained water at the well head and only the steam is used to generate electricity. Some of the thermal energy of the hot water can be ut1lized by multiple flashing of steam from the water at successively lower pressures. Attention is being directed currently both by private industry in this country and by the U.S.S.R. government towards developing other generating systems that would utilize some of the thermal energy stored in the hot water. In these systems, the hot water is piped under pressure to a heat exchanger where the is

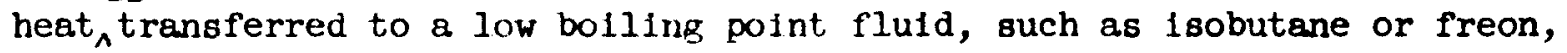
which in turn is fed into the turbine. The spent water, still under pressure, Is then reinjected. Successful development of other generating methods Including this binary-fluid generating technology would allow more complete extraction of heat from geotherwal fluids and allow use of hot-water reservolrs of lower temperature than presently required, greatly expanding our usable geothermal resources. 
Geothermal resources have other uses, but to date they have been minor. Geothermal waters as low as $40^{\circ} \mathrm{C}\left(104^{\circ} \mathrm{F}\right)$ are used locally for space heating and horticulture. Much of Reykfavik, the capital of Iceland, 1s heated by geothermal water, as are parts of Rotorua (New Zealand), Bolse (Idaho), Klamath Falls (Oregon), and various towns in Hungary and the U.S S R. Geothermal steam is also used in paper manufacturing at Kawerau, New Zealand, and has potential use for refrigeration and alr conditioning. Some geothermal waters contain potentially valuable by-products such as potassium, 11thium, calcium, and other chemicals. Use of geothermal energy to desalt geothermal water 1tself has been proposed, and the U.S. Bureau of Reclamation and Office of Saline Water are presently developing a pllot operation for producing fresh water from the geothermal waters of the Imperial valley, southern California.

Generation of electricity from natural steam in the United States at the present time is limited to The Geysers, California, which has an installed capacity of $192 \mathrm{Mw}$, whth an additional $220 \mathrm{Mw}$ under construction. Geothermal resource utilization, however, 18 recelving increasing attention from private Industry, public utifities, and county, state, and Federal agencles because of the likely future energy shortage (and increased prices for electrical power) throughout the United States and the consequent need to evaluate and develop new sources for electrical production other than fossil fuel, nuclear, and hydroelectric. Furthermore, passage of the Geothermal Steam Act of 1970 (P.L. 91-581) gave the Secretary of the Interior the authorit to issue leases for the development and utilization of geothermal ateam and 
assoclated geothernal resources on Federal lands, where many of the most promising areas aro located. Lessing of Federal land for geothermal exploration, however, has been deluyed pending satisfaction of the requirements of section $102(2)(\mathrm{c})$ of the National Environmental Pollcy Act of 1969, as interpreted in recent court decisions. The first leasing of Federal lands under the "grandfather alause" is anticipated for September 1972, with subsequent lease sales at approximately six-month intervals. Industry interest and activity in geothermal exploration and development has burgeoned in 1971 and 1972. An active development drilling program at The Geysers has added materially to the reserves. Deep exploratory drilling has taken place in the Jemez Mountains, New Mexico, at Clear Lake, California, at Mono Lake, California, and in the Imperial Valley, California. The great interest in geothermal exploration is illustrated by the attendance of 650 people at a meeting of the Geothermal Resources Counc1l in El Centro, February 16-17, 1972. The interest in geotherma?. developments is not limited to vapor-dominated reservoirs, such as The Geysers, but is directed in part towards finding hotwater reservotrs. 
CHAPTER 4

\section{CUETENT KESEARCH AND TEVELOPMGNT}

\section{International}

Geothermal resources exploration and development programs have been conducted for many years by agencies of the Itallan, Icelandic, and New Zea]ani governments. The first power generating station to use natural steam for electricity was established at Larderello, Italy, in 1904, and since that t lme the 1 tallian government has expanded the development of the Field and carried out exploration for other geothermal fields. Iceland started heatirig homes and industries in Reykjavik in 1930, and has for several decedes carried out a program of exploration to evaluate the 18land's geothernal resources. The New Zealand goverment developed the Wairake1 geothermal field for elestric power generation after World War II, and has also carried out an exploration program for other geothermal resources, resulting in successful discovery of the Kawerau and Broadlands fields. Sclentists, engineers, and technicians largely from these countries, the United States, and Japan have staffed a vigorous geothermal exploration and development program in underdeveloped countries by the United Nations. The UN has sponsored several. internat lonel conferences that have spurred development of the field, a conference on "New Sources of Energy" at Rome in 1961, and in cooperation with the Italian government a "Symposium on the Development and Utilization of Geothermal Resources" at Pisa, Italy, in 1970. The UN has sent technical assistance missions to advise on the potential of geothermal resources to Argentina, Cameroon, Chile, China (Taiwan), Costa Rica, E1 Salvador, Ethiopla, Greece, Gutemela, Ind1a, Israel, Jordan, Kenya, Mali, 
Mexico, Nicaragua, the Philippines, Tunisia, and Turkey, and to the Dominica and St. "ucia Islands (West Indles Assoclated States). Larger scale projects, which include geological, geophysical, and geochemical surveys as well as exploratory drilling, have been carrled to the fleld development stage in Chile, El Salvador, and Turkey, and are currently in the exploration stage in Ethiopia and Kenya. As the result of these efforts, the decision has been made to construct a $30 \mathrm{Mw}$ plant in El Salvadore (the engineering design Is now in progress) and decisions are inminent regarding the construction of a small geothermal power faclilty at a field discovered in Turkey (Koenig, 1972). In the last decade Russia, Japan, and Mexico have carried out successful exploration and development programs for geothermal energy. An effort by the U.S.S.R. government that is of particular interest is the construction of a binary-fluid generating unit using intake water of $81^{\circ} \mathrm{C}\left(178^{\circ} \mathrm{F}\right)$ at Paratunka, Kamchatka. Other exploration and development programs have been carried out by the French government in Guadeloupe, the Republic of China in Taiwan, and the Philippine govermment, and surveys for geothermal resources have been conducted in Greece, Costa Rica, Israel, Rwanda, Canary Islands (Spain), Tanzania, Colombia, Uganda, and Morocco. In Nicaragua and Indonesia geothermal exploration has been conducted partly with loan funds from the U.S. Department of State Aid for International Development Program. Emphasis in all these programs has been on exploration and development, but they have also yielded, particularly in New Zealand, Iceland, and Italy, noteworthy advances in our understanding of the geothermal resources and how to develop and utilize them. Current research and development, 
excluding field development and plant construction, by other countries and the United Nations engages several hundred scientists, engineers, and technicians at a cost of several tens of millions of dollars.

United States of America:

Research and development programs in geothermal resources have been carried out in the United States by several Federal agencies, state agencies in most of the western states, and private industry. The following descriptions of Federal agency programs were prepared from material supplied by the agencies. At the time of this writing (June 1972), f1scal year 1973 programs have been submitted to Congress by the agencies but funds have not yet been appropriatedand allotted. Fiscal year 1974 programs for all agencles are still in the planning stage. 


\section{U.S. Geological Survey}

Prior to 1971, the U.S. Geological Survey had no speclally funded geothermal resources program, although modest investigations of hot springs and geothermal phenomena were carried out as part of the Geologic Division investigations of energy and mineral resources. Modern Geological Survey hot-spring studies were begun by Donald E. White in 1945 at Steamboat Springs; the initial emphasis was on mechanisms of ore transportation and deposition, but the results of a decade of study proved to have important application to the understanding of geothermal resources. Beginning in 1963, the focus of Geological Survey geothermal research shifted to the Salton Sea geothermal field, in particular, to cooperative studies with private industry focused on the geochemistry and petrology of the hydrothermal system. In 1966, the Geological Survey began a major investigation of all aspects of the geology of Yellowstone National Park, including intensive studies of the hot-spring areas. Studies included geologic mapping, geophysical surveys, sampling and analysis of hot springs, and the drilling of 13 research holes to depths as great as 1100 feet. Several other hotspring systems in the western United States have been investigated by the Geological Survey, Including Sulphur Bank on Clear Lake, California, and the Lake City area. A very useful source of information for geothermal exploration is the Geological Survey compilation of temperature and other data on thermal springs (Waring, 1965). In addition, other studies by the Geological Survey have proved important to geothermal resources, including heat-flow studies, determination of silica solubility, development of the silica, $\mathrm{Na} / \mathrm{K}$, and $\mathrm{Na}-\mathrm{K}-\mathrm{Ca}$ geothermometers, and experimental studies of rock alteration. 
In August of 1971 the 92nd Congress appropriated an increase of $\$ 500,000$ to the Geological Survey for an expanded geothermal program. As a result (1) the staff for classifying Federal lands for geothermal resources was increased and preparations were made for lease management; (2) projects were started at The Geysers/Clear Lake and Long Valley, California, using detailed geologic, geophysical, geochemical, and hydrologic techniques; (3) reconnalssance geologic, geochemical, and hydrologic surveys were started in northwestern Nevada and southeastern Oregon: (4) a program was started for developing and testing new geophysical techniques (electrical, electromagnetic, passive seismic, and thermal infrared); and (5) laboratory studies were started on hydrologic modeling, solution chemistry, and geochemical indicators of reservolr temperatures.

A $\$ 1,800,000$ increase in the Geological Survey geothermal program has been proposed to Congress for FY 1973 to support in augmented program including a number of new research projects, supervision of operations on geothermal leases, and the classification of additional geothermal resource areas. New hydrologic studies will be undertaken on the Island of Hawail and in the Jemez Mountains, New Mexico. Ceophysical studies of these and other areas will be broadened to include microselsmic and telluric methods as well as heat flow at shallow to moderate depths. The physics, temperatures, and hydrology of several geothermal areas will be modeled using computer technology. Subsurface temperatures and hydrologic parameters 
in the Gulf Coast area will be studled. Reconnalssance surveys will be started in Alaska and expanded in the western states, and chemical analyses of water and rock samples will be supplemented with lsotopic analyses. Environmental effects of geothermal developments--such as ground subsidence and earthquake activity--will be monitored with initial emphasis on the Imperial Valley, California.

The Geological Survey has planned an expanded 5-year program starting in FY 1974 to be carried out if funds are made available. The program would include (1) classification and lease supervision, (2) environmental monitoring and evaluation, (3) pre-lease evaluation of geothermal areas and development of better exploration techniques through detalled fleld studies including research drilling, (4) regional reconnaissance studies, and (5) brine disposal studies. 
Bureau of Reclamation

The Colcrado River Basin Act (Pub11c Law 90-537) requires the Secretary of the Interior to make reconnalssance studies for the purpose of developing a general plan to meet future water needs of the Western United States and to determine the most ecoriomical method of augmenting the flow of the Colorado River by 2,500,000 acre-feet per year. Th1s work has been delegated to the Bureau of Reclamation. A promising source to meet both of the above requirements is the geothermal resources in the Imperial Valley of California, by desalting the hot geothermal brines underlying the Reclamation withdrawn lands. Reclamation and the University of California, Riverside, began a joint exploratory program to evaluate the geothermal potential of these lands in 1968.

The Bureau of Reclamation and the Office of Saline Water have recently undertaken a joint 7 -year research and development program with an estlmated cost of $\$ 16$ million ( $\$ 9.7$ million for the Bureau of Reclamation) to determine the feasibility of multi-purpose development of electric power and desalted water from the geothermal resources of Imperial valley. This program was begun in FY 1972 with an appropriation of $\$ 800,000$. An increase of $\$ 400,000$ in the Reclamation geothermal program has been proposed to Congress for FY 1973 to accelerate the program, which is designed to determine the quantity and quality of hot geothermal brines underlying Reclamation whdraw lands, to develop the technology for total development of the geothermal resources, to demonstrate the feasibility of developing large quantities of desalted water, and to determine on the best plan for delivery of desalted water to the Colorado River. This effort is and will continue to be coordinated with other 
investigations aimed at determining the potential of the resource for power generation and recovery of chemicals and gases.

An additional $\$ 5.7 \mathrm{milli}$ ion effort is needed by the Bureau to explore in areas of critical water shortages, other promising geothermal areas having a potential for producing low-cost water supplies in the western States. This exploration is necessary to assure that all potential alternatives for water supplies have been evaluated. In the early stages, this program would concentrate on the exploration and the evaluation of the resource for water production rather than on research and development similar to that presently being carried out in the Imperial Valley. To meet the requirements of Public Law $90-537$, this evaluation must be completed no later then 1977 .

The components of the Bureau of Reclamation geothermal program are listed below:

1. Exploration-- The exploration program is designed to secure a reasonable appraisal of the quantity and quality of geothermal resources on Reclignation withdrawn lands in the Imperial Valley in the shortest practical time. Methods employed w1l be geologic and geophysical investigations combined with relatively shallow (1,500 feet or less) temperature gradient drill holes and a limited number of production wells to production depths of 5,000 to 7,000 feet. Verification of water quality will be necessary to assure that desalting and electric power generation techniques will be applicable to the entire production area. 
A reasonably reliable estimate of the quantity of the seothermal resources on Federal lands in the Imperial Valley (almost all of which are Reclamation withdrawn lands) wlll be needed at an early date for a decision on the source of replacement water to prevent subsidence due to fluld withdrawal. If the resource proves to be large, the most economical source is the ocean. If the resource is moderate or small, local replacement water from such sources as near surface ground water, the Salton Sea, and the Wellton-Mohawk Drain would be used. If the total quant1ty of the resource in the Imperial Valley is of sufficient size to permit large-scale importation of replacement water from the ocean, then the entire resource could be developed as a joint venture by Federal and non-Federal interests to develop water and power at the lowest cost.

2. Production and injection wells.--Sufficient production vells must be drilled in the research and development stage to verify the results of the exploration program. The production wells must also be operated in conjunction with injection wells for a sufficient period of time to determine the best well spacing and well diameter. Environmental effects such as selsmic activity, subsidence, and air pollution will be monitored in conjunction with the operation.

3. Research and development.--Research and development activities will be required in various fields in order to support the desalting efforts. The best size and spacing of both production and injection wells will be anaiyzed. Injection techniques including disposal of byproducts will be studied. The 
integration of electric power production and desalting will be studied with the goal of optimizing benefits from both these products and poselble mineral byproduct recovery. Subsidence, selomic activity, and other environmental impacts that could result from geothermal resource development w1ll be investigated and procedures developed to modify or eliminate adverse effects. The answer to these problems should be applicable in whole or in part to the natlonwide development of geothermal resources.

4. Appraisal.--The results of the research and developwent program must be carefully analyzed and appraised to provide answers to enviromental problems and the character and magnitude of the resource and the economics of desalting appraised to assure that the tcital potential is realized in the national interest. 
The Office of Saline Water started a $\$ 6,300,0007$-year geothermal program in FY 1972 almed at developing the technology necessary to the desalting of geothermal brines. The program objective is to develop economical and technically feasible processes for the production of high quality water. In addition, the desalting processes must be made compatible with other processes based on the geothermal resource, such as power production and mineral producing processes, to permit an optimal and comprehensive geothermal development. The studies are centered on the geothermal brines in the Imperial Valley, California, and are carried out in close collaboration with the Bureau of Reclamation. A large part of the technology developed there should be applicable to the desalting of other geothermal brines.

In FY 1973, the program will be carried out at a level of $\$ 800,000$, subject to congressional approval of appropriation, and wlll include research on brine chemistry, materials of construction, process analysis and testing, environmental effects of the desalting processes, and effluent disposal techniques. Efforts in brine chemistry will include research on the composition of geothermal brine and its reactions within the desalting plants and the effluent disposal system, determination of the extent of scaling of process equipment and research on means to reduce the effects of scaling to a minimum, and research on the chemical nature of the deep-well disposal system and related chemical reactions. Attention w11l be directed towards finding economical and reliable materials of construction for the potentially corrosive geothermal fluid--a hot, acidic brine containing sulfide and carbonic gases. 
Procoss parameters, including heat-transfer coefficients and flashing characteristics, will be determinos, well as the effective design of equipment components. Methods will be asvelopel to permit the inclusion of the desalting plant into an integrated power-water-mineral geothermal

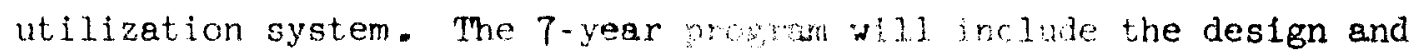
construction of a 200,000 to $500,000 \mathrm{gpd}$ pilot desalting plant in FY 74 and a 2 to 3 million god prototype plant in FY 76 . 


\section{Bureau of Mines}

The Bureau of Mines has for many years carried out programs that relate generally to geothermal resources research needs, such as extraction, processing, use, reuse, and disposal of minerals and minerel fuels, but has not carried out an identified geothermal program until the present. In FY 1973, the Bureau will undertake a $\$ 160,000$ geothermal effort almed at developing improved drilling muds and improved cements for use in drilling and casing geothermal wells at temperatures as high as $350^{\circ} \mathrm{C}\left(662^{\circ} \mathrm{F}\right)$. Starting in FY 1974, the Bureau of Mines propcses to begin a 5-year expanded program principally aimed toward the recovery of minerals and gases dissolved in geothermal fluids. Reject brines from a water desalting plant would constitute the feed material for mineral recovery processes; non-condensible gases probably would be delivered from a separate power plant. Research investigations would concentrate on the geothermal fluids of the Imperial Valley in addition to other promlsing geothermal resource areas. If research indicates the presence of mineral and gas constituents of sufficient economic value in the brines, a pllot plant for their recovery could be built in close proximity to a desalination plant in order to receive and process the plant effluents.

The Bureau of Mines geothermal program has the following six goals: (1) to develop a system for the evaluation of brines, determining constituents of potential economic value, (2) to develop methods for recovering constituents so determined, (3) to develop methods for separating noncomnercial constituents and disposing of them, (4) to determine criteria 
for selecting materials of engineering construction needed in the handing of hot commercial brines, (5) to find new metallurgical processing uses for residual brines, and (6) to improve drilling muds and cements 0 as to lower costs of tapping geothermal resources. 
As manajer of the Public Lands, the Bureau of Land Management is responsible for leasing of Federally-owned geothermal resources in compliance with the spirit and objectives of the Geothermal Steam Act of 1970, the National Environmental Policy Act of 1969, other legislation, and supporting Executive Orders and regulations. The Bureau's geothermal leasing program will be at a level of $\$ 200,000$ in FY 1973, subject to Congresslonal approval of appropriation, and the Bureau has proposed an expanded 5-year program beginning in FY 1974.

Initially, the Bureau's geothermal leasing program will be directed primarily at adjudicating conversion rights established by Sec. 4 of the Act, and to leasing of lands of known or potential value for geothermal resources. Competitive lease offerings w1ll result for lands confirmed to be of value for geothermal resources. Other lands wll be avallable for non-competitive leasing, which will proceed concurrently with the competitive leasing program. The expanded program would consist of the following compenents: (1) identification of potential geothermal leasing tracts based on Geological Survey, Bureau of Mines, and Bureau of Land Management data and evaluation; (2) development of a tentative leasing schedule; (3) consideration of environmental factors and land-use plannings for each lease tract; (4) evaluation of resource, cost, and market data including the refinement of Geological Survey estimates of bonus bids for each leasing tract; (5) post-sale evaluation of tracts; (6) development and maintenance of professional competence; (7) development and maintenance of a computer system including all available resource and 
land-use data on areas identified for geothermal leasing; and (8) conduct of a study program to update and refinc leasing regulations and procedures, pre- and post-sale evaluation procedures, and environmental considerations. 


\section{National Science Foundation}

The Research Applications Directorate of the National Science Foundation began a careful consideration of the need for geothermal energy research at the end of Fiscal Year 1971 but did not sponsor any projects until FY 1972. Four projects have been sponsored in FY 1972, and several others are under serious consideration. The sponsored projects are described below: 1. "Investigation of the Thermal Regime of the Rio Grande Rift System of New Mexico" by Marshall Reiter of the New Mexico Instltute of Mining and Technology ( $\$ 24,900 / 24$ months). A geophysical investigation of the thermal regime of the Rio Grande rift system of New Mexico is being conducted in order to help assess the rift's possible potential as a large scale source of geothermal power. The Rio Grande rift displays many geological and geophysical characteristics indlcative of both the mid-oceanic ridges and presently producing geothermal sites. Heat flow data are being acquired over the extent of the rift in New Mexico and several profiles normal to the rift will be sought.

2. "Geothermal Resources Research Conference" by Walter J. Hickel of the University of Alaska $(\$ 56,500 / 8$ months). The objective of the conference on reothermal resources research is to develop an assessment of the stateof-the-art and to recomend a research program to provide the requisite. knowledge for establishing the proper role of geothermal resources in providing (1) additional energy to alleviate the Nation's impending shortage, (2) water to supplement present supplies, (3) and mineral resources. 3. "Stimulation of Geothermal Aquifers" by Paul Kruger and Henry Ramey of Stanford University ( $\$ 141,500 / 12$ months). The research has three major objectives: (1) development of experimental and numerical data to evaluate 
the optimum performance of explosion-stimulated geothermal aquifers, (2) development of a geothermal steam reseryolr model to evaluate the thermophysical, hydrodynamic, and chemical parameters involved, (3) development of a laboratory model of an explosion-produced chimney to obtain experimental data on the processes of in-place bolling, moving flash fronts, and two-phase flow in hot porous media, as well as chemical and radiochemical data for the fluids produced.

4. "Investigation of Hydrothermal Systems at K1lauea Volcano, Hawa11" by George Keller of the Colorado School of Mines ( $\$ 462,500 / 12$ months). Kilauea volcano, Hawall wll be used as a geothermal field research laboratory to evaluate groundwater movement in the vicinity of a maga chamber. Kilauea volcano can provide a means for testing some of the physical concepts that have developed about the characteristics of hydrothermal systems. The project goal is to provide positive evidence about groundwater dynamics in a hydrothermal system and to provide a model for other geothermal systems 80 that effictent exploration approaches can be developed. The major part of the program will be the drilling of a test hole at a site selected to provide the best chance of intersecting a hydrothermal convection cell above the Kilauea magma-chamber, but the program would also include supplementary geophysical studies of the sumit area of the volcano, physical tests in the drill hlle, and measurements on recovered samples.

The NSF Research Applications Directorate estimates (Congress willing) in FY 1973 that it will provide approximately $\$ 1,500,000$ in the Inergy 
Conversion section of the Energy Research and Technology program and $\$ 500,000$ in the Energy Resources section. The Energy Conversion portion will concentrate on the science and technology of utilizing geothermal resources whereas the Energy Resources portion wll emphasize evaluation, exploration, etc., for the resource. 
Unt 11 the present line, the Atomlc Energy Comm1solon has not had a formal geothermal resources program, but several investigations carried out, unier AFC's auspices durtng, the last few years relate directly to research and development needs of geothermal energy. In 1970 and 1971 a detailed study was conducted by a team from Battelle Northwest, American Oil Shale Co., Westinghouse, Inc., AEC and the Lawrence Livermore Laboratory of the technical and economic feasibility of extracting thermal energy from relatively ary geothermal reservolrs through the use of nuclear explosives to fracture the rocks and the subsequent injection of water to provide a carrier for the heat. At the LOs Alamos Sclentific Laboratory another project involves the development of a thermal drill using heat generated electrically. A prototype of the drill has been successfully tested in the laboratory and in the field. Preliminary studies have been conducted at the same laboratory of the feasibility of the use of hydraulic and thermal fracture techniques to expose large heat transfer surfaces in a hot but relatively dry geothermal reservoir in order to recover the energy for power generation. In addition, Battelle Northwest has conducted laboratory studies of silica and radio-nuclide leaching from rock melted by underground nuclear explostons.

In response to inquiries, the AEC stated before the Senate Appropriations Committee that if funds were made avallable a program of research and development contributing to the wide-scale use of geothermal resources and their conversion into economic electric power could begin at about a level of $\$ 2,000,000$ in FY 1973. Primary emphasis would be placed on initial examination of the feasibility of extracting ener(sy from relat1vely dry geothermal reservolro 
thromph the Injection and recovery of water in a high-presoure syatem. Thi: clfort would include study of the behavior of dry geothermal reservolrs as they are cooled and energy is extracted in order to determine the effect of a hydraulic fracture system and the possible expansion of this system by thermal-stress cracking to expose additional heat transfer surface. Laboratory and preliminary field preparation would be undertaken on the feasibility, methods, and economics of developing dry geothermal reservolrs by circulating cooling water through hot rock exposed by hydraulic fracturing techniques. The geothermal provinces of concern would be those where there is abundant hot rock (about $300^{\circ} \mathrm{C}$ or more) but where there is little or no mobile ground water because of the low permeability of the rocks. Assessment and evaluation would also be undertaken of methods to stimulate production of geothermal fluids from known geothermal provinces which do not produce steam or hot water of sufficient temperature, quantity, or purity as to be economically usable in power generation. It is believed that stimulation techniques similar to those that have been successful in the ofl and ges industry may be of value in these areas. Studies would be undertaken of the mass transport of silica as well as the chemical, hydraulic and thermal characteristics of natural geothermal systems in order to develop methods for removal of impurities and to develop generating plant equipment compatible with geothermal fluids. These studies would provide information leading to the development of models for evaluation of the economic potential of geothermal systems and techniques for power generation as well as the cost-effectiveness of geothermal research and development programs. 
Beginning with engineering analysis of existing technology, a program would be undertaken to develop efficient binktry-fluid conversion systems for lower temperature or highly corrosive geothermal flulds in order to maximize the electrical generating capacity of the thermal energy and to enlarge the range of productive geothermal fluids. 


\section{Department of Defense}

Advanced Research Projects Agency

The Advanced Research Projects Agency has started study to Invest1gate the potential applications of geothermal energy sources to specific military needs. It is possible that a number of pover requirements for the Services can be satisfied with geothermal energy sources much smaller than those necessary for comerclal power production. Possible military applications of geothermal energy of interest to the Department of Defense include (1) primary source of reliable power at remote locationa, (2) an emergency or back-up power source in the event conventlonal porer sources are dismpted, and (3) a self-contalned, stand-by power source for hardened underground or underwater facilities capable of providing space heating and cooling, and usable water as well as electric power.

The ARPA effort is limited to the definition of Departient of Defense needs, definition of the research and development required to apply geothermal energy technology to a variety of military requirewents, and to a pilot study of a specific geothermal reservolr adjacent to an existing militar; facility to determine the research necessary to develop this type energy source for selected milltary needs. 
The National Aeronautics and Space Administration has carried out for several years cooperative research with the U.S. Geological Survey in the remote sensing of thermal areas. In this program, data from Geological Survey fleld and laboratory studies and aerial photographs were augmented by infrared scanner data and high altitude aerial photographs provided by NASA. This cooperative program will continue into space through Geological Survey proposals selected by NASA for analysis of data from ERTS-A (July 1972 launch) and Skylab (April 1973 launch).

ERTS television and multispectral imagery wil contribute indirectly to geothermal studies through analysis of snowmelt and vegetation anomalies. Addition of emitted infrared imagery with Skylab will permit direct observation of thermal anomalles, with anticipated ground resolution of approximately $80 \mathrm{M}$ and $0.4^{\circ} \mathrm{K}$ temperature sensitivity. In addition to the above, NASA plans to keep abresst of research and development in geothermal resources in order to assist in basic technology wherever possible. In carrying out its responsibilities NASA has developed during the last decade capabilities in many disciplines, technologies, and techniques. The particular problems in the field of geothermal resources to which NASA may be able to make contributions in cooperation with user agencies include material dévelopment, heat conversion cycles, and silencers development, pipe flow and compressor design. 
Natural resource agencles of many of the western States are carrying out geothermal studies. In California the Division of Mines and Geology ns well as the Department, of Water Resources and Division of 011 and Cas have conducted noteworthy geothermal progrems for many years including appraisal of the State's resources and geologic Investigations of the producing field at The Geysers and several promising areas in the state. The Oregon Department of Geology and Mineral Industries and the New Mexico Bureau of Mines and Mineral Resources have also conducted productive geothermal programs for many years, resulting in the cataloguing of hot spring data in both States and the geologic analysis of favorable areas. Useful geothermal resources programs are also being carried out by the Nevada Bureau of Mines and Ceology, the Idaho Bureau of Mines and Ceology, and natural resource agencies of Alaska, Arlzona, Colorado, Montana, Utah, and Washington. Altogether, geothermal research and development studies by State agencies, most of which are almed at resource appraisal, Involve several dozen sclentists and engineers at an annual funding level of perhaps half a million dollars. 
Slgniflcant exploration and development programe for geothermal resources in the United States have been conducted by prirate industry only for the last two decades. The first plant in the United States to generate electricity from natural steam was put into production in 1960 by Pacific Gas and Electric Company, based on steen produced by nom Power Company and Thermal Power Company. In the ensuing years these latter companies and Union 011 have carried out successful development of The Geysers field together whth exploration of promising areas elwewhere in the western United States. A few other companies, largely petrolou companies, joined in these activities in the $60^{\prime} \mathrm{s}$, but interest on the part of private industry was not widespread until passage of the Geothermal stem Act of 1970 opened the possibility of leasing Federal lands for geothermal development.

Private industry has supported geothermal research and development by industry staff, university consultants, and other companies in all the toplc areas listed in th1s report. Because of the general lack of knowledge in the field, each exploration program is a research project. The developant of The Geysers field has led to increased knowledge of the recource and the development of new techniques of reservoir development and production. The attempted development of the Salton sea geothermal field required research and development on power generation and mineral recovery technology using concentrated geothermal brines. Industry has supported engineering design studies of binary-fluid power generating technology, and plans to construct a pilot plant of this nature if sufficient private capital is found. 
Some of the knowledge resulting from industry research and development has been made available to other scient1sts and engineers in the field of geothermal resources through the exchanges at scientific meetings, formal publications, etc., but much remains confldential because of 1ts competitive value. The total current effort in geotherwal research and development by private industry in the United States is not known, but it very probably amounts to several tens of millions of dollars per year apart from costs of land purchase, production drilling, and plant construction. 
Relevant Research DIrected at Other Bnergy Resources

Some of the research and development needs in the fleld of geothermal resources are not unique to that field but are the subject of research and . development projects under other programs. Moteworthy research and development projects in this regard include: (1) drilling technolosy (petroleum industry and Federal rapid-excavation programs), (2) well-logging and sampling techniques (petroleum industry), (3) brine-rock interactions (Federal fluid-waste-disposal programs), (4) brine chemistry and desalination technology (Federal desalination programs), (5) binary-fluid power generation (private ut1lities and Federal programs on bottom cycles), (6) removal of $\mathrm{H}_{2} \mathrm{~S}$ from steam (private utilities and Federal a1r pollution control programs), and (7) reduction of nolse (private industry). The total funding for relevant research and development and the applicability of such $R$ and $D$ to the needs of geothermal resources is not known, but it should be thoroughly invest1gated before funding new geothermal programs. 
CHAPTER ;

ENVIRONMENTAL EFFECTS

Considerable attention has been drawn to geothermal resources as an electrical generating mode that cun have a relatively small adverse effect on the environment. Geothermal energy does not produce atmospheric particulate pollutants as do fossil fuel plants: nor does it require fuel to be mined or transported, handled, or consumed; in addition, there is no production of radioactive waite nor potantial for nuclear disaster. Present geothermal penerating plants to not require a supplementary source of cooling water, in contrast to other thermal generating piants. The power plant must be located close to the site of the peothermal ure, and the environmental effects are therefor" local in extent.

Geothermal power, however, is not without adverse impact on the environment. An analysis of the environmental effects of geothermal power was made in the Iraft Environmental Inpact Statement for the Geothermal Leasing Program issued by the Department of Interior in September 1971. In this analysis, the environmental efferts to be expected during the exploration, test drilling, production testing, feld development, power plant and power line ccistruction, and full scale production phases are outlined. The enviromental effects of vapor-dominated and hot water systems are significantly different and are treated in detail. The major possible problems are thermal effects, land despoilment, contamination of ground-and surface-waters, noxious gases, noise, land subsidence, and supply of cooling water for closed-system generating modes. The remote possibility of increasing seismic frequency or intensity by increases or decreases of fluld pressure 
in a tectonically active environment 18 also a consideration for some fielde. With proper manemement and technology, and at some cost, all adverse environmental effects could be held to acceptable levels.

Geothermal energy has the unfavorable aspect of greater water consumption and waste thermal discharge per unit of electricity than elther nuclear or fossil fuel modes because of the lower turbine conversion efficiencies at the low geothermal steam pressures and temperatures. A geothermal field and power plant utilizes more land than would an equivalent nuclear or foss1l power plant. Present reser'roir development ut1lizes several wells spaced at about 20 acres each to supply a small central power plant. The field is laced with steam pipes radiating out from pover plants connected together by high-voltage power lines. In the present state of technology the visual impact of areas of geothermal development 18 heavy, and such areas must be classified as industrialized regions. Land use conflicts may be expected frequently to arise on this account. Although the actual space requirement of the field is large compared to that of a fossil fuel or nuclear power plant, the total requirement is in reality smaller than many of these systems when mining of materials and waste disposal are considered. Multiple land use of the field for agricultural and other purposes is possible in many areas.

Vapor-dominated systems, such as The Geysers, yield relatively pure steam low in noxious content. The condensates (about $20 \%$ of the feed fluid) are reinjected into the reservolr. Non-condensible gases at The Geysers are less than $1 \%$ of the steam and consist predominantly of carbon dioxide with 
less abundant ammonia, methane, hydrogen sulfide, nitrogen and hydrogen. Hydrogen sulfide is the most objectionable component because of 1ts unpleasant odor, and there is at the present time no completely suitable technique for its removal fran the steam. Although research is currently being conducted into methods of its removal at The Geysers and in other energy resource fields, additional research is needed to solve the problem.

Nolse during well-cleanout and well-bleeding stages of geothermal development causes a problem in dry steam flelds, and the nolse during well drllling is a problem attendant to all geothermal fields (as well as to other energy resources). Better mufflers need to be developed to hold the noise to acceptable levels.

Hot-water systems generally yleld large quantities of warm water that commonly is mineralized and presents a chemical pollution hazard to surface and ground waters. Most proposed geothermal developments in the United States, however, plan to dispose of the waste water by reinjection into the geothermal reservoir in which cases contamination of surface waters and useable ground water should not be a problem. In some cases, it may be practical to purify or treat the water for removal of these contaminants, but even so, residuel brines will need to be disposed of by reinjection into. the producing reservoir. The pilot project planned by the office of Saline Water for the Imperial Valley will test the practicality of rater desalinization treatment.

Another problem posed by removal of large volumes of water and heat from some reservoirs is that of land subsidence (Hunt, 1970). Subsidence may occur in the few geothermal reservolrs that are found in relatively 
unconsolidated sedimentary rocks, such as those that fill intermountain basins in the western United States. In some areas such as the Imperial Valley of Californta, subsidence could cause major problems by the disruption of irrigation canals, plpelines, and so forth. During field development or the production stages in critical geothermal flelds, subsidence should be monitored, and if it is greater than an acceptable amount, a program of relnjection should be inftlated to control the subsidence.

At those hot-water geothermal fields where the geothermal flutd is extract:d from the reservolr, ut1lized for power generation with a method such as the binary-fluid system, and relnjected back into the reservolr-all in a closed system under pressure--large supplies of cooling water for the power generation cycle will have to be provided from an external source, Just as it has to be provided for conventional power generation plants. Supply of large quantities of such cooling water may present a problem in some areas such as the arid Basin and Range provinces of the western United States.

Finally, when large volumes of fluids are removed or injected in a tectonically active enviroment, there is the remote possibility that the resulting change in fluid pressure could increase the incldence of earthquakes by a mechanism similar to that demonstrated for the Rocky Mountain Arsenal Well (Healy and others, 1968). Provisions should be made to monitor seismicity of those geothermal flelds that lie astride faults that could generate ma, ior earthquakes. 
Est Imates of the geothermal resources of the UnIted States and the impact of the utilization of these resources on the Nation's energy needs differ by more than a thousand times. For example, calculations based on D. E. White's (1965) estimate indicate that 5,000 to $10,000 \mathrm{Mw}$ could be generated and maintained for at least 50 years under present economic conditions and technoloey. Kilkenny (1972), in the course of a study by the "New Energy Forms Task Group" of the Nat1onal Petroleum Council, estimates that generating capacity based on geothermal flulds in the United States, specifically in Callfornia and Nevada, wll increase to between 7,000 and $19,000 \mathrm{MW}$ by 1985 . R. W. Rex in testimony before the Senate Interfor and Insular Affalro Committee on Fuels and Energy Policy (Congressional Record, June 15, 1972) stated that wh a successful auginented Federal research and development program, a generating capacity of 400,000 Mw based on geothermal resources could be developed in the western United States within the next 20 years. The wide variation in resource estimates reflects a number of factors including different assumptions about technological developments and cost factors, preparation of different estimates for different reasons (for example, legal requirements versus program justification), and different uses of the terms "resources" and "reserves", but the major cause of the broad spread in estimates is a lack of factual knowledge of the resource itself. 


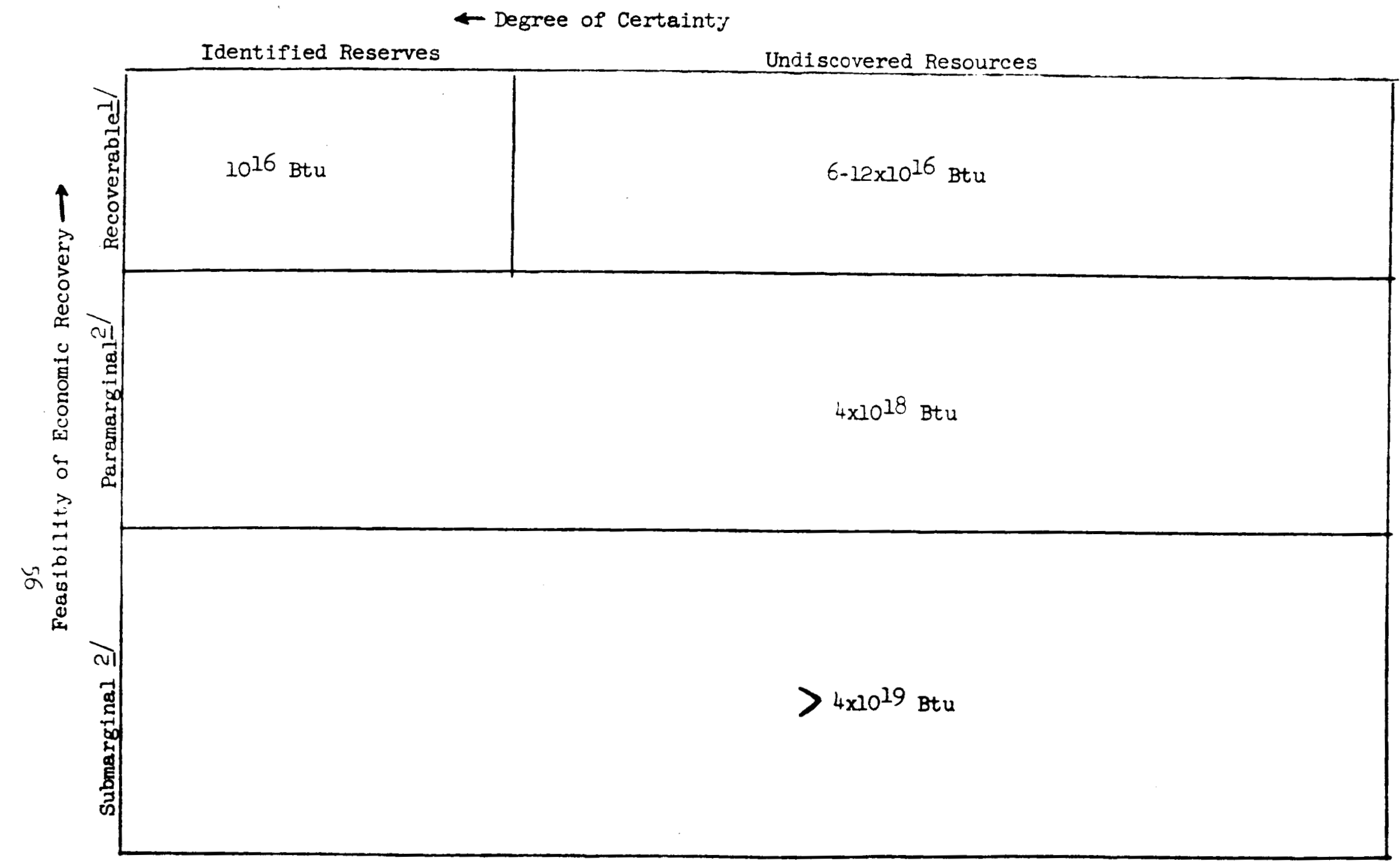

1) figures shown are energy at the well head

2) figures shown are energy in situ

Figure 2. Estimated reserves and resources of geothermal energy 
Conservative estimates of geothermal reserves and resources are shown in the diagram of figure 2, which 1s based on the format of McKelvey (1972). Reserves and resources should be distingulshed from the "resource bese," which is defined by Schurr and Netschert (1960, p. 297) as all of a given material present in the earth's crust, whether 1ts existence 18 known or unknown and regardless of cost considerations. For geothermal resources, the resource base is all of the heat in the earth's crust above mean surface temperature (about $15^{\circ} \mathrm{C}$ ). White $\left(1965^{\circ}\right)$ estimates the heat in the earth's crust to a depth of $10 \mathrm{Km}$ to be about $10^{24} \mathrm{Btu}$, equivalent to 2000 times the world's coal reserves. Grossling (1972) estimates that the heat stored in the crust of the United States in cratonic and platform rocks to a depth of $10 \mathrm{Km}$ and in interstitial water in sedimentary basins to be $2 \times 10^{22} \mathrm{Btu}$. Only a small proportion of the geothermal resource base, hovever, can be considered a resource. Extraction of all the heat in the crust not only would be uneconomic but also might cause problems such as ground movement and earthquakes caused by the resulting thermal stresses. Exactly what proportion of the geothermal resource base can be considered a resource depends on a number of factors, such as depth of extraction; assumed temperature distribution to that depth; effective porosity, specific yield, and permeability of the reservoir rocks; physical state of the fluid (water or steam); available technology; economics of various uses; and government policy with respect to research and development, leasing, environmental constraints, etc. Different assumptions as to technology, economlcs, and government policy have caused much of the large variation in published estimates of geothermal resources. 
Table 2.-- Three recent sets of geothermal resource estimates.

Estimated Geothermal Reserves and Resources

(L.J.P. Muffler and D.E. White, in Theobald, 1972)

Identified resources

Undiscovered recoverable and submarginal resources to a depth of $10 \mathrm{~km}$
$10^{16} \mathrm{Btu}$ (at the well head)

$4 \times 10^{19}$ Btu ( $\left.\underline{\text { in s1tu }}\right)$

Forecast of Geothermal Power Generation Capacity in Megawatts (J. E. Kilkenny, 1972)

\begin{tabular}{|c|c|c|c|c|}
\hline Cost per kwh (in mills) & 1,70 & 1975 & 1980 & 1985 \\
\hline 5.25 & 82 & 1500 & 4500 & 7000 \\
\hline 5.75 & & & 4000 & 7000 \\
\hline 6.25 & & & 2000 & 5000 \\
\hline & $\overline{83}$ & 1500 & & 19000 \\
\hline
\end{tabular}

Estimated Geothermal Reserves

R. W. Rex (written comm. May 1972)

Megawatt centuries of electricity (in thousands)

\begin{tabular}{|c|c|c|c|}
\hline $\begin{array}{l}\text { Fuel Price } \\
\text { mils/kwh } 1 /\end{array}$ & $\begin{array}{l}\text { Known } \\
\text { Reservesel }\end{array}$ & $\begin{array}{l}\text { Probable } \\
\text { Reserves } 2 /\end{array}$ & $\begin{array}{l}\text { Und iscovered } \\
\text { Reserves 2/ }\end{array}$ \\
\hline $2.90-3.00$ & $13 /$ & $53 /$ & 10 \\
\hline $3.00-4.00$ & $304 /$ & $4005 /$ & $2,0006 /$ \\
\hline $4.00-5.00$ & $?$ & 600 I/ & $12,0008 /$ \\
\hline $5.00-8.00$ & $?$ & $?$ & $>20,0009 /$ \\
\hline $8.00-12.00$ & $?$ & $?$ & $>40,000^{10} /$ \\
\hline
\end{tabular}

Footnotes on following page: 
I/ A fuel price of $2.90 \mathrm{mils} / \mathrm{kwh}$ is equivalent to a power cost (as shown in the estimate by Kilkenny) of $5.25 \mathrm{mil} / \mathrm{kwh}$. Assumptions include the following:

Recovery of 50 percent. in in situ thermal energy in the hot water reservolrs

Power conversion efficiencies of 20 percent for vapor-dominated reservoirs and 14 percent for hot-water reservolrs

Present costs and prices inflated by $5 \%$ per year for the next 30 years

22 percent depletion allowance for geothermal energy

Energy price in present dollars

Development by tax-paying entities

10 percent royalty to landowner (Federal or State governments, or private land holders)

No severance taxes

State taxes at a level no higher than the California Corporate rate No increase in Federal corporate taxes

Cost of capital $8.5 \%$

Expensing of intangible drilling expenses

No change in the depreciation rate for amortizing wells

2/ Note that the term reserves as used by Rex differs from the usage by Muffler and wi:te and in the text of this report.

3/ Vapor-dominated reservoirs, primarily The Geysers area, California

4/ Deeper vapor-dominated reservolrs, primarily in the Clear Lake/Geysers area and high-temperature hot-water reservolrs in the Imperial Valley, Callfornia

if Deeper vapor-dominated reservoirs and high-temperature reservolrs in the above areas plus Jemez mountains, New Mexico, and Long Valley, California

Ef Deeper vapor-dominated reservolrs and high-temperature reservolrs in the above areas plus the remainder of The Basin and Range province, western United States

I/ Intermediate-temperature hot-water reservoirs and deep high-temperature hotwater reservoirs in the above areas plus Hawall and the over pressured hot brines of the Gulf Coast

8/ Same as above plus hot-water reservoirs in Alaska

9/ Hot dry rock syștems at less than $6 \mathrm{~km}$ depth over ; percent of western U.S., development based on hydrofracturing or cost-equivalent technology; cost estimate based on present drilling technology and could be reduced by new low-cost drilling technology

10/ Hot dry rock systems as above between $6 \mathrm{~km}$ and $10 \mathrm{~km}$ depth 
The identified recoverable geothermal resources of the United States (excluding National Parks) are estimated in figure 2 to be $10^{16}$ Btu, based on the estimate of Muffler and White (1972) of $6 \times 10^{16}$ Btu in the ground, including measured, indicated, and inferred resources. This estimate includes the vapor-dominated reservolrs at The Geysers as well as several high-temperature hot-water reservoirs elsewhere in the western Unfted States. As only about 15 percent of this is deliverable to the well head with current technology, the total reserves (at the well head) are thus $10^{16} \mathrm{Btu}$ or enough steam to generate $1000 \mathrm{Mw}$ for 50 years at the current generating efficiency of 14 percent. In comperison, R. W. Rex (Table 2) estimates that reserves in the vapor-dominated reservolrs at The Geysers alone would support $1000 \mathrm{Mw}$ for 100 years.

Undiscovered recoverable geothermal resources (defined as those resources recoverable at cost competitive with alternative forms of energy) are estimated in figure 2 to be $6-12 \times 10^{16}$ Btu at well head, based on White's (1965) estimate of geothermal resources recoverable as electricity to a depth of $3 \mathrm{Km}$ in the United States (assuming that 1 percent of the in situ heat is recovered as electricity). This resource would support 3000-6000 Mw generating capacity for 50 years. The estimate is for the generation of electricity using proven and conventional technology, thus the geothermal reservoirs included in the estimate must have temperatures of at least $180^{\circ} \mathrm{C}\left(356^{\circ} \mathrm{F}\right)$, because at lower temperatures the quantity of flash steam is inadequate, and would include vapor-dominated and high-temperature hotwater systems. 
In comperison, Rex estimates (Table $?$ ) that there are sufficlent vapordominated reservoirs, primarily at. The Ceysers, to support 15,000 Mw generating capacity for 100 years. Kilkenny (Table 2) has not estimated resources explicitly, but his forecast of future geothermal pover production implies at least minimum estimates of resources. He has, for example, estimated that there will be $7000 \mathrm{Mw}$ installed capacity by 1985 with costs of $5.25 \mathrm{mills} / \mathrm{Kwh}$ (i.e., production based on vapor-dominated systems). Paramarginal resources are estimated in figure 2 to be $4 \times 10^{18} \mathrm{Btu}$ in situ, sufficient to support $40,000 \mathrm{Mw}$ generating capacity for at least 50 years. These resources would consist largely of high-temperature (>180 $\mathrm{C}, 356^{\circ} \mathrm{F}$ ) hot-water systems that might be developed economically at the present time or in the near future. Critical economic factors wll be the cost of reinjecting waste fluids and the successful development of binary-fluid or other efficient generating systems and multipurpose (1.e., power-water-chemicals) utilization technology. Much attention 18 presently being given to the generation of electricity from genthermal waters, using a system whereby the geothermal heat is used in a heat exchanger to boll a secondary fluid such as isobutane or freon, which drives the turbine. A generating unit based on the heat-exchange princlple and using intake water at $81^{\circ} \mathrm{C}\left(178^{\circ} \mathrm{F}\right)$ is reported to be in pilot operation at Paratunka, Kamchatka, U.S.S.R. (Facca, 1970). Industry interest in this generating mode in the United States is high, and englneering design for a pllot plant using isobutane has been completed, although construction of the pilot plant has not been undertaken. Multipurpose developments yielding power, desalted water, and/or recovered chemicals improve the economics of power generation by sharing 
a significant part of the costs against other products. Several projects of this type are currently in the development stage, including the El Tatio field, Chile, under UN sponsorship, and the Imperial Valley, California, by the Bureau of Feclamation and the Office of Saline Water. Kilkenny (Table 2) estimates that successful application of these technologies at somewhat higher costs $(5.75-6.25 \mathrm{mills} / \mathrm{kwh})$ will result in the installation of an additional $6000 \mathrm{MW}$ generating capacity by 1980 and 12,000 Mw by 1985. Rex (Table 2 ) includes in known reserves high-temperature hot-water reservoirs of this quality largely in the Imperial Valley, as well as deeper vapor-dominated reservolrs at The Geysers, which are sufficlent to support a generating capacity of $30,000 \mathrm{MW}$ for 100 years. He estimates that additional resources of this type in the western conterminous United States are sufficient to support $2,400,000$ Mw generating capacity.

Recoverable geothermal resources could be still further expanded by technological breakthroughs that would permit the economic development of resources that are clearly not economic at the present time. These submarginal resources are estimated to be more than $4 \times 10^{19}$ Btu by Muffler and White (Table 2) and sufficient to support more than 400,000 Mw generating capacity for 50 years. Such possible developments include the (1) successful application of power generating technology to geothermal reservoirs of intermediate and low temperatures, that is, cooler than $180^{\circ} \mathrm{C}\left(356^{\circ} \mathrm{F}\right)$; (2) development of better methods for recharge of fluids in geothermal reservoirs, thus permitting fuller and longer utilization of the heat stored in both rocks and fluids of the reservoir; (3) development of techniques of artificial stimulation to 
increase the productivity of geothermal reservoirs, and in combination with the introduction of fluids, to tap the heat stored in hot dry rocks; (4) improvements in existing drilling techniques as well as the development of new drilling techniques that would allow economlcal drilling to greater depths; (5) new technology that would favor wider utilization of lowtemperature geothermal resources for space heating, product processing, agriculture, etc. As these techniques are successfully developed, the recoverable geothermal resource will expand within the limit set by the U.S. geothermal resource base. R. W. Rex (Table 2) estlmates that the resources present in intermediate-temperature hot-water reservolrs and in deep reservoirs of vapor-dominated and hot-water type in the western United States, the Gulf Coast area, Alaska, and Hawai1, could support 12,600,000 Mw for 100 years. In addition, he estimates that the successful development and application of technology for recovering the thermal energy from hot dry rocks could add resources sufficient to support more than 20,000,000 Mw generating capacity at depths of less than $6 \mathrm{~km}$ and an additional 40,000,000 Mw at depths between 6 and $10 \mathrm{~km}$.

An estimate of the impact of geothermal resources on the Nation's energy needs over the next 30 years can be gained from the following estimates of the magnitude of installed power generation capacity based on geothermal resources:

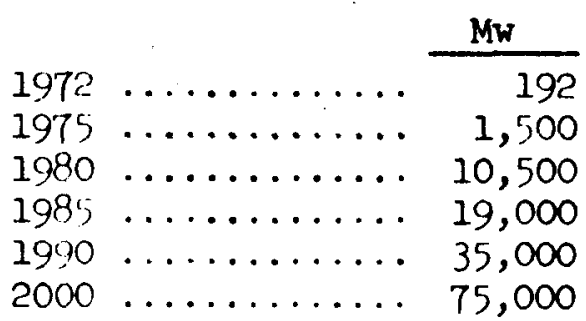


For the years 1975 through 1985 we have accepted the estimates of John E. Kilkenny (197?) because of his position as an official in one of the very few companies in the United States engaged in the exploration, development, and production of geothermal resources at a profit. The estimates are for power generating capacity at costs of $6.25 \mathrm{mills} / \mathrm{kwh}$ and less (at current prices), and are based on the assumption that technologies will be developed for the economic generation of power from hot water reservoirs as well as for the multipurpose utilization of some geothermal resources such as those of the Imperial Valley. A larger Federal research and development program than that assimed by Kilkenny could bring about an earlier application of the technology and result in greater installed capacity in 1985 than that shown. The estimated increase in power generating capacity beyond 1985 to $35,000 \mathrm{Mw}$ in 1990 and 75,000 Mw in 2000 is based on the assumption that an expanded Federal research and development program will result in the identification $\mathrm{cf}^{\prime}$ more geothermal reservolrs and the development of technologies for generating power from deeper and lower temperature geothermal fluids including the over-pressured geothermal brines of the Gulf Coast. The successful development and application of technologies for the economic recovery of thermal energy from reservoirs with insufficient fluids or permeability might result in an even greater increase in geothermal-based generating capacity. 


\section{CHAPTER 7}

\section{RESEARCH AND DEVELOPMENT NEEDS}

Resources Appraisal

More precise estimates of the magnitude, quality, and distribution of geothermal resources in the United States are essential in developing a Federal strategy for meeting the future energy needs of the Nation. Current estimates by knowledgeable experts of potential geothermal power generation differ by several orders of magnitude, in part because of different assumptions about technology but also in part because of the lack of sufficient data on which to base the estimates. The delineation and evaluation of the different geothermal provinces of the United States, an essential first step in determining the geothermal resources of the Nation, would also provide useful information for planning by public utility districts, and the identification of specific promising areas and evaluation of the approximate magnitude and quality of their geothermal resources would provide useful background information for the ultimate recovery of the thermal fluids and production of power. For promising areas on Federal lands, the information gained under this program will be

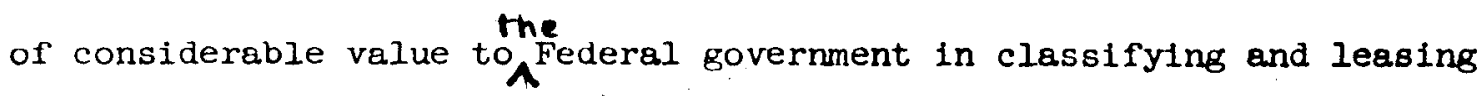
public lands under the Geothermal Steam Act of 1970, as well as for supervising the resulting leases.

In order to determine the magnitude of the geothermal resources within the next few years, an aupmented Federal program of regional studies, heatflow measurements, and research drilling is needed. Part of this effort should be focused in selected regions of high geothermal potential which 
could be delineated as National Geothermal Fleld Laboratorles. Regional studies would include geologic mapping and synthesis, geochemical sampling : and analysis, and geophysical studies including both ground and airborne methods. The program is closely related to the program of development of improved Exploration Methods. A greatly increased program of heat-flow measurements in moderate depth drill holes (200-300 m) across the country would provide data essential to delineating the major geothermal provinces and should also help in identifying specific favorable target areas. Drilling of deep (mostly $>1000 \mathrm{~m}$ ) drill holes is an essential element of this program, as well as the programs in Exploration Methods and in Reservc.r Development and Production. The deep drilling is needed to determine in the third dimension the characteristics of geothermal reservoirs, such as temperature, pressure, rock composition, structure, and fluid composition. Drilling of shallow $(200 \mathrm{~m})$ holes and measurements of temperature gradients will also be a necessary part of the program in detailed study of some areas.

A program of very deep drilling, to depths as great as $10 \mathrm{Km}$, is essential for evaluating the geothermal potential of the deep crust beneath the United States. Such a progrial willd require $\$ 10 \mathrm{million}$ to $\$ 20$ million per year for the drilling of 1 to $?$ boreholes per year. We recommend that this program be deferred until after the development of better, cheaper techniques for deep drilling and the demonstration that hot, relatively dry rocks at depth can be artificially fractured to form a viable geothermal reservoir. 
The initial level of funding recommended for this program is $\$ 6$ million, of which $\$ 2$ million is for reconnaissance studies, $\$ 2$ million for heat-flow measurements and related drilling, and $\$ 2$ million for other drilling programs.

Exploration Methods

Development of geothermal resources and evaluation of their magnitude are handicapped by the relatively primitive nature of exploration techniques currently in use, by the absence of an adequate understanding of the factors that characterize geothermal systams, by the lack of Inexpensive techniques for drilling, and by the need for better borehole logging and sampling techniques. Better methods are needed both to detect geothermal areas during regional reconnaissance and to determine the bize and power potential of an area once it has been found. At the present time the most reliable technique for the discovery of new geothermal reservolrs is to search out areas of hot springs--a situation analogous to that in the petroleum industry in the early $1900^{\prime} s$ when petroleum exploration consisted of drilling surface oil seeps. A variety of geophysical, geochemical, and geologic methods are now being applied to the exploration for geothermal resources. Many of the successful exploration methods used in exploration for mineral and petroleum deposits are also applicable to geothermal exploration although in a different setting, and several new methods show promise. Research is needed on the different techniques and on the methodology of applying them to geothermal exploration. Furthermore, a better understanding of geothermal reservoirs, such as the three-dimensional variation in 
temperature, the circulation of geothermal fluids, and the pattern of feochemical alteration of reservoir rocks and deposition of minerals, would lead to better techniques for discovering and developing geothermal f'ields. Drilling is a large component in exploration, development, and production of geothermal fields, because of the use of (1) shallow (200 meters) temperature-gradient holes in exploration, (2) holes of the same or somewhat greater depth for heat-flow measurements in defining geothermal provinces, (3) deeper drill holes for proving the existence of a geothermal reservoir and determining its extent, and (4) production wells for tapping the reservoir. Faster, safer, and less expensive drilling techniques for both shallow and deep holes and both slim exploration holes and greater-diameter production wells, would ald greatly in the discovery and development of geothermal fields and in the production of steam and hot water from them. Research and development is needed both to improve existing techniques and to develop wholly new techniques. Existing techniques for logging boreholes and sampling fluids from them are not completely satisfactory for geothermal exploration, in part, because of the high temperatures and corrosive fluids of geothermal reservoirs. Development of better techniques would have an immediate practical application in evaluating exploration holes and would also further the effort to gain a better understanding of geothermal reservoirs.

An expanded Federal prograni to develop better exploration methods is recommended, with initial funding at an annual level of approximately $\$ 5$ million. Of this amount, about $\$ 1$ million should be allotted to 
development of better drilling techniques, $\$ 1$ million to better borehole loprint lechniques, and $\$ 3$ inlllion to the development of other exploration methods. Among the latter, reophyslcal methods, particularly electrical prospecting techniques using, both natural and induced currents, show the most promise and should receive the most emphasis. Other methods that deserve attention include the following: electromagnetic, microearthquake and seismic noise monitoring, seismic refraction and reflection, remote sensing using infrared and multispectral techniques, temperature gradient measurements, geochemical methods, particularly analysis of thermal waters, gravity, magnetics, and geologic analysis. Efforts to develop better exploration methods probably should be focused largely on only a few representative geothermal flelcs in order to avold scattering the Federal effort. Designation of certain fields as National Geothermal Laboratories could help channel efforts in that direction. The drilling program described under the section on Resources Appraisal is an essential element in the program, and efforts should be made in addition to provide the maximum amount of data from deep holes drilled by private industry. Reservoir Development and Production

Geothermal fields are currently developed using equipment and methods similar to those used in developing petroleum fields. However, the nature of geothermal reservoirs, particularly the temperature, pressure, state, and composition of the geothermal fluids, and unknown porosity, thickness, and permeability of the host rock introduces some different problems that hinder development of the resource. Furthermore, the lack of experience on the 
part of both exploration and utility companies in developing geothermal fields snd producing stenm from them results in time delays and added costs in developing a field, that is, in drilling production wells and demonstrating that they will yleld sufficient steem over a sufficlently long period of time to justify construction of power plants. Part of the problem would be helped by research and development under "Exploration Methods," particularly the development of improved techniques for drilling and for borehole logging and sampling. However, an additional need is for the development of better computer models for geothermal fields (Whiting and Ramey, 1969; White and others, 1971), models that w11 aid in predicting the Iffe and quality of the fleld and that can be used to determine the best well spactint, and production rate. Development of successful models will depend in part on assembling sufficient data on temperatures, pressures, hydrology, etc., of a field, using data both from industry (see Cady, 1969; Bilhartz, 1971; Cady and others, 1972), and from drilling and research carried out under the Resource Appraisal and Exploration Methods programs. A problem in some geothermal fields is the deposition of carbonate in production or reinjection wells and the deposition of sillca is a possible problem in some fields. Research is needed on the geochemistry of geothermal fluids, (White, 1964, 1970, 1971) including fluid-rock interactions and mass transport of silica and carbonate, and development is needed on practical methods of preventing deposition of silica and carbonate and removing scale once it has formed. 
Other research and development proprams could lead to the extension of the size or life of geothermal reservoirs and to the extension of geothermal resources to a new type of resource. A research and development program on methods of recharge by reinjection (including the modeling of the reservoir under recharre) could lead to longer production from fields. Artificial stimulation of geothermal reservolrs by hydraulic fracturing, thermal-stress fracturing, and fracturing by explcitives could extend both the life and size of a field, and could reduce the cost of drilling by producing tractures at shallow depths in a reservoir (Raghavan and others, 1971; Ramey and others, 1972). This invectigation should include the development of better and chesper chenical explosives for use at the high temperatures found in geothemal reservolrs. Cothermal reservolrs have been found which lack sufficient permeability to support geothermal development; other hot rock masses mity exist at depth which also lack suf'ticient f'luids, although the existence of such masses has not been demonstrated. Possibly the thermal energy stored in such hot but relatively dry rocks could be tapped by first using, the above techniques to form a permeable reservoir and, if necessary, then clrculating water through the reservoir (see Kruger and otte, 1972).

An expanded Federal research and development program is recommended to investigate these subjects. Funding needs for the f'lrst year would be about $\$ 5$ million. $\$ 2$ million is needed for (1) modeling geothermal reservoirs, (2) investigating recharge methods, (3) investigating the 
geochemistry of geothermal fluids, and (4) developing technlquee for detecting and removing scale and preventing its deposition. Another $\$ 3$ million is needed to investigate the artificialostimulation of geothermal reservoirs and the feasibility of tapping the thermal energy stored in hot, relatively dry rocks.

Utilization Technology and Economics

The technology for generating power from dry steam fields such as The Geysers and from certain wet steam fields, such as Cerro Prieto and Wairakei, is well developed. In dry steam fields the steam is avallable at well head at low pressure compared to that used in conventional fossil fuel or nuclear-powered plants; abrasive particles are removed, the steam is fed to turbines of special design because of the low steam pressure. In wet steam fields, hot water in the geothermal reservolr flashes into a mixtiure of steam and water upon reduction of pressure by the well; the steam and water are separated at the well head, and the steam, which is Elso at relatively low pressure, is fed to a turbine; the separated water may be flashed again at lower pressure ylelding steam at still lower preseure. No Federal research and development program is needed for power generation technology for these fields--that is, for dry steam fields or for wet steam (hot-water) fields where temperatures exceed $180^{\circ} \mathrm{C}\left(356^{\circ} \mathrm{F}\right)$ and the geothermal brines are dilute.

However, there appear to be abundant geothermal reservoirs that do not meet this criterion, and for these Federal research and development on power generation technology are needed. Furthermore, Federal research and 
development is needed on other utilization of geothermal resources, particularly desalination of brines and comnercial recovery of chemicals. Possibly 70 to 80 percent of the geothermal reservolrs susceptible to development within the next decade or so contain hot water at insufficient temperature (less than $180^{\circ} \mathrm{C}, 356^{\circ} \mathrm{F}$ ) or have dissolved chemical of such a nature or abundance that they cause problems in power generation. Successful demonstration that these reservoirs can be ut1lized economically for generating electrical power would greatly expand recoverable geothermal resources. Private industry in the United States, and the U.S.S.R. lovernment, have made some progress toward developing techniques for using these geothermal fluids for generating power; the technlques are besed on binary-fluid systems in which the heat is transferred to a low-boiling point fluid (such as isobutane or freon) which is fed to the turbines. Federal research is needed to examine a variety of power generation methods for dilute geothermal brines, including binary-fluid systems as well as other power cycles using hot concentrated brines. Federal development funds may be needed for desipn and construction of demonstration power plants, although at least one such binary-fluid plant may be constructed by industry using private funds.

A Federal research and development program is also needed to develop and demonstrate the technology for desalting geothermal brines and recovering chemicals and gases from them in combination with power generation. The successful demonstration of multiple use of geothermal fluids would help in expanding the recoverable resource by sharing plant 
costs amone, different uses. In many areas of the world, desalted water milght be a far more valuable product than the electric power. The Department of Interior geothermal resources program in the Imperial Valley, California, is aimed at demonstrating the utility of such a multiple use of geothermal fluids.

The research and development described above, as well as the development of drilling and better borehole logging techniques, will requlre the development of materials (alloys, cements, plastics, etc.) resistant to the high temperatures and corrosive fluids. The economic modeling of both single and multiple use of geothermal fluids and of power generation from different geothermal fluids using different power cycles should be an element in the research program.

The needs for an expanded Federal Research and Development program on Utilization Technology and Economics are estimated to be $\$ 6,000,000$ for the first year, including $\$ 3,000,000$ for power generation techniques including economic modeling, and $\$ 3,000,000$ for techniques of desalination and recovery of chemicals.

Environmental Effects

Although geothermal energy has probably less impact on the environment per kilowatt capacity than other generating modes such as fossil fuel and nuclear power, it is not without adverse environmental effect. Of particular concern in dry steam fields are emission of $\mathrm{H}_{2} \mathrm{~S}$ and nolse from well cleanuut and bleeding; in hot-water fields possible deleterious effects include 
contaminition of surface and pround whters, substdence, and possible froneration of earthquakes and supply of cooling water for closed system ifenerating modes. A Federal proxram of research, development, and monitorine is needed to insure that adverse environmental effects do not hinder the development of geothermal energy. A priority 11st of elements of the program follows:

1. Monitoring of quality of surface and ground waters. in regions of geothermal developments. Although reinjection of geothermal fluids into the producing zone at most if not all geothermal flelds developed in the United States should result in no impairment and perhaps even an improvement in the quality of surface waters and shallow ground waters in each individual field, the quality of the water should be determined before development of the field and monitored periodically thereafter. Research on reinfection of geothermal fluids, listed under the program on Reservoir Development and Production, has obvious applications to this program on environmental effects. Although some data exist on natural amissions from thermal areas and chemical composition of surtace and ground waters, an expanded program, including research on sampling techniques, will be required to establish base-level values.

2. Research and development on the technology for removal of hydrogen sulfide gas at the well head, at other points of steam emission, and from power plant exhausts. Hydrogen sulfide, which is easily detected in small concentrations by its offensive odor, is present in many geothermal steam 
fields. In highly sensitive individuals, exposure to hydrogen sulfide beyond the threshold of odor can cause nausea or other illness. Although air-pollution control equipment has been developed for other industries and applied to geothermal fields, emission of hydrogen sulfide from geothermal developments is still a problem requiring Federal research and development funds.

\section{Development of technology for reducing noise from drilling} operations and from well cleanout and bleeding. The development of a geothermal field extends over a period of years, and the machinery noise from drilling operations and roar of steum from wells under development make geothermal operations incompatible with residential or recreational land use. The problem has been reduced somewhat during the last few years by use of mulflers, but further reseurch and development : meded on the redin ion of noise by various means of sound baffling and improved mufflers and muffling techniques during a11 pheses of geothermal development and production. other research should be directed at reducing to a minimum the disruption of the ecolugic system of a geothermal area by installations and operations.

4. Monitoring of land subsidence. Geothermal developments that involve removal of large volumes of water from a geothermal reservoir in relatively

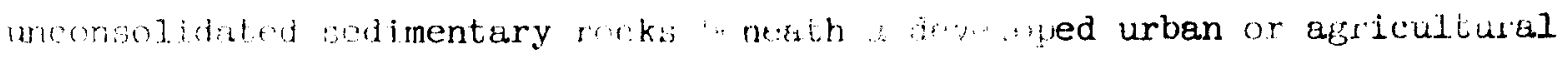
area may result in undesirable subsidence causing disruption of irrigation canals, changes in local elevation with respect to sea level, etc., unless most of the spent brines are reinjected into the reservoir. The planned Imperial Villey geoth:rmal develipment is such a project. For such 
levelopmentis, monitoring of surface elevations by neans of repeated leveling survey: lo essential and a modifled relnjection proeram may be necessary.

$\therefore$ Monltoring of seismic nctivity. Some geothermal flelds that will be developed within the next few years may be in areas that have undergone damaging earthquakes in the past. The Imperlal Valley field, which lies astride the San Andreas fault system is an example. Changes in the fluid pressure within these flelds from withdrawing and reinjecting fluids may change the pattern of strain release in the area. Although the possibility of causing damaging earthquakes by these methods seems to be remote, a modest program of seismic monitoring should be carried out in the few areas thut: nppoil haznrious.

The needs for the first year of an Environmental Effects program are estimated to be $\$ 1.5$ million, including $\$ .5$ million for research and development of air pollution and noise reduction techniques, and $\$ 1$ million for monitoring environmental effects.

Institutional and Legal Aspects

A variety of functions and problems have been included in this category even though some are not of a research and development nature. All, however, are essential or desirable for the full development of geothermal resources.

Federal programs directed toward the management of the geothermal resources of the public lands are necessary for the development of the Nation's geothermal resources, many of which underlie public lands. The Bureau of Land Management and the Geological Survey have responsibility 


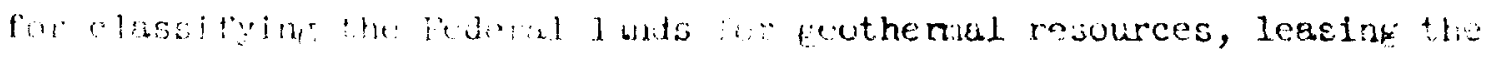

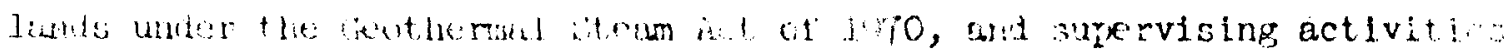
on the lexised lirils.

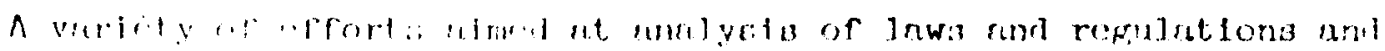

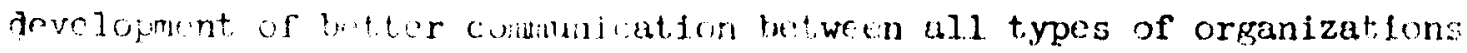
involved in the "othermal resources fleld could help considerably in the devolopment of the field. Such ef fortis include the following: (1) to comple State, fecierul, and county laws and resulations concerning geothernila

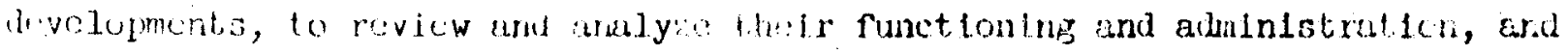
constder dosirable encndacnts; (2) to prepare a nodel code; (3) to analyzo the

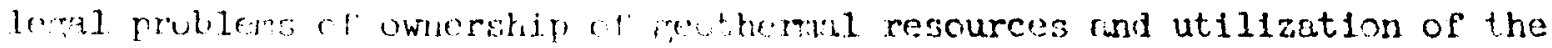

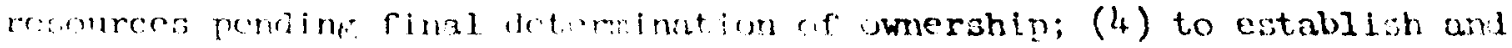
maintain liaiscri between lederal, itute, and local asencles, the acudern community, and the pothermial industry and to explore nechanisme of rooperetion betweon these g, roups thut would enhance industrial apjlicaticn

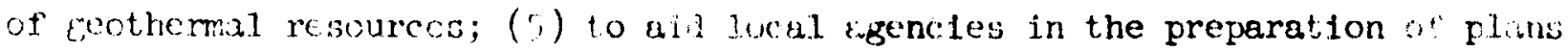
for the crierly developncent of lock reothermal resources; (6) to estahlish a central feceral froility for the sytometic eathering and rapid distribution W intormation on frotherral resoures; and (7) to evaluate the need for geothemal field researeh leburaterizs.

The needs in FY 1974 for the Pederal progrem of munagement of the geothermal resources of the public landis are estimated to be $\$ 1,000,000$. An additional $\$ 500,000$ is needed for the other legal and institutional. activities listed above. 


\section{REFERENCES}

American 0 il Shale Corporation 1971, Battelle-Northwest, Westinghouse Electric Corporation and Lawrence Livenmore Laboratory, Feasibility study of płowshare geothermal power plant.

Austin, D. F., 1966, Selection criteria for geothermal prospects in Papers presented at the AIME Pacific Southwest Mineral Industry Conference, Sparks, Nevada, May 5-7, 1965; Part C, Session on North American exploration and Mine Development: Nevada Bureau of Mines Report 13, p. 93-125.

Axtel1, L. H., 1972, Overview of geothermal exploration and development in California, presented at the Geothermal Resources First National Conference, El Centro, California.

Baker, C. A., 1972, Geothermal Power, Scientific American, v. 226, no. 1, p. 70-77.

Barton, D. B., 1970, Current status of geothermal power plants at The Geysers, Sonoma County, Cal ifornia: U. N. Symp. on Dev. and Util. of Geothermal Resources, Pisa, Italy.

Biehler, S., Kovach, R. L., and Allen, C. R., 1964, Geophysical framework of the northern end of the Gulf of California structural province, in Marine Geology and Gulf of California, a symposium: Am. Assoc. Petroleum Geologists Mem. 3, p. 126-143.

Biehler, S. and Rex, R. W., 1971, Structural geology and tectonics of the Salton trough, southern California, in Geol. Soc. America Cord. Mtg., Riverside, March, Field Trip Guidebook: Geol. Excur. in So. California p. 30-42.

Bilhartz, H. L., Jr., 1971, Fluid Production from Geothermal Steam Reservoirs, MS Report, Stanford University, Stanford, California.

Bodvarsson, G. D., 1970 , Evaluation of geothermal prospects and the objectives of geothermal exploration: Geoexploration, v. 8, p. 7-17.

Boldizar, T., 1970, Geothermal energy production from porous sediments in Hungary: U.N. Symp. on Dev. and Util. of Geothermal Resources, Pisa, Italy.

Bowen, R. G., 1971, Electricity from geothermal, nuclear, and coal sources. An environmental impact comparison; The Ore Bin, Oregon Dept. of Geol. and Mineral Industries v. 33, no. 11, p. 197-212.

Bowen, R. G., and Peterson, N. V. 1970, Thermal springs and wells in Oregon: Oregon Dept. of Geol. and Mineral Industries Misc. Paper 14. 
Bowen, R. G., and Groh, E. A., 1971, Geothermal - earth's primordial energy. Technology Review, p. 42-47, Oct/Nov.

Bowen, R. G, 1972, Overview of geothermal exploration and development in Oregon, presented at the Geothermal Resources First National Conference, El Centro, California.

Bradbury, J. J. G., 1970, The economics of geothermal power (Rapporteur's Report): U. N. Symp. of Dev. and Util. of Geothermal Resources, Pisa, Italy.

Burnham, J. B., and Stewart, D. H., 1970, The economics of geothermal power: Pacific Northwest Laboratories, Battelle Institute, Richland, Wash., $18 \mathrm{p}$.

Cady, G. V., 1969, Model Studies of Geothermal Fluid Production. Ph.D. Dissertation, Stanford University, .Stanford, Cai iforri.

Cady, G. V., Bilhartz, H. L., Jr. and Ramey, H: J. Ramey, Jr., Model Studies of Geothermal Fluid Production, Presented at 7lst National Meeting, American Institute of Chemical Engineers, Dallas, Texas, Feb. 1972,

Cal ifirnia, Department of Water Resources, 1967, Investigations of geothermal waters in the Long Valley area, Mono County.

California Division of $0 i 1$ and Gas, 1971, California Lawa for conservation of geothermal energy.

California Division of $0 i 1$ and Gas, 1971, Map of the Geysers geothermal field.

Cal ifornia Division of $0 i 1$ and Gas. 1971, Map of the Salton Sea geothermal field.

California Geothermal Resources, 1967, Report to the 1967 Legislature by the Joint Legislative Committee on Tide Lands, 194 p., 75 p.

Campbel1, K. V. and others, 1970, A survey of thermal springs in Washington State: Northwest Science, v. 44, no. 1, p. 1-11.

Clayton, R. N., Muffler, L. J. P., and White, D. E., 1968, Oxygen isotope study of calcite and silicates of the River Ranch No. 1 well, Salton Sea geothermal field, California: Am. Jour. Sci., v. 266, p. 968-979.

Combs, Jim and Muffler, L. J. P., 1972 Exploration for geothermal resources: Trans. Amer. Nuclear Soc., 1972 Annual Mtg., Las Vegas, Nev.; June $18-22,1972$, p. 15.

Crosby, J. W., III, 1971, New developments in geothermal exploration: lst Northwest Conf. on Geothermal Power, Dept. of Natural Resources, Olympia, Washington. 
Decker, Edward, 1972, Overview of geothermal exploration and development in Wyoming, presented at the Geothermal Resources First National Conference, El.Centro, California.

Decius, L. C., 1964, Geological environmental of hyperthermal areas in continental United States and suggested methods of prospecting them for geothermal power: U:N. Conf. New Sources of Energy, Rome, 1961 , Proc., v. 2, Geothermal Energy: I, p. 166-177,

Ellis, A. J., 1970, Quabtitative interpretation of chemical characteristics of hydrothermal systems: U.N. Symp. on Dev. and Util. of Geothermal Resources, Pisa, Italy.

Facca, G., 1970, General report of the status of world geothermal development (Rapporteur's Report): U. N. Symp. on Dev. and Util of Geothermal Resources, Pisa, Italy.

Fournier, R. 0. and Kowe, J. J., 1966, Estimation of underground iemperatures from the silica content of water from hot springs and wetsteam wells: Am. Jour. Sci., v. 264, p. 685-697.

Fournier, R. 0. and Truesdel1, A. H., 1970, Chemical indicators of subsurface temperature applied to hot spring waters of Yellowstone National Park, Wyoming, U.S. A.: U. N. Symp. on Dev. and Util of Geothermal Resources, Pisa, Italy.

Garside, L. J., 1972, Overview of geothermal exploration and development in Nevada presented at the Geothermal Resources First National Conference, El Centro, California.

Geothermal Resources Board, California, Compendium of Papers, Imperial Valley - Salton Sea Area Geothermal Hearing, Oct. 22 and 23.

Geothermal Resources Board, California, 1971, Economic Potential of Geothermal Resources in California, $35 \mathrm{p}$.

Goodwin, L. H., Haigler, L. B., Rioux, R. L., White, D. E., Muffler, L. J. P., and Wayland, R. G., 1971, Classification of public lands valuable for geothermal steam and associated geothermal resources: U. S. Geol. Survey Circ. $647,18 \mathrm{p}$.

Goldsmith, M., 1971, Geothermal Resources in California, potentials and problems; California Ins. Tech. Enviromental Quality Laboratory report no. $5,45 \mathrm{p}$.

Griscom, A., and Muffler, L. J. P., 1971, Aeromagnetic map and interpretation of the Salton Sea geothermal area, California: U.S. Geol. Survey, Geophys. Inv. Map GP-754. 
Gron, E. A., 1966, Geothermal energy potential in Oregon: The Ore Bin, Oregon Dept. of Geology and Mineral Industries, v. 28, p. 125-135.

Grose, L. T., 1971, Geothermal Energy: Geology, exploration, and developments, part 1, Colorado School of Mines Mineral Industries Bull. v. 14 , no. 6,14 p.

Gross, L. T., 1971, Geothermal Energy: Geology exploration and developments, part 2, Colorado School of Mines Mineral Ind. Bull. v. 15, no. 1, $16 \mathrm{p}$.

Grossling, B. F., 1972, An appraisal of the prospects of geothermal energy in the United States, part 1, in chapter 2, Geothermal energy, of In Initial Appraisal of the New Energy Forms Task Group 1971-1985: Washington, D. C. , NATL. Petroleum Council, p. 15-26.

Haigler, L. B., 1969, Mineral and water resources of Arizona: Arizona Bur. Mines Buil. 180 .

Harrenstein, Howard, 1972, Overview of geothermal exploration and development in Hawaii, presented at the Geothermal Resources First National Conference, El Centro, California.

Harshbarger, J. W., 1972, Overview of geothermal exploration and development in Arizona, presented at the Geothermal Resources First National Conference, El Centro, California.

Healy, J. H., Rubey, W. W., Griggs, D. T., and Raleigh, C. B., The Denver earthquakes; Science v. 161, no. 3848, Sept. 1968, p. 1301-1310.

Hewitt, W. P., 1972, Overview of geothermal exploration and development in Utah, presented at the Geothermal Resources First National Conference, El Centro, California.

Heylmun, R. C., 1956, Geothermal power potential in Utah: Utah Geological and Mineralogical Survey Special Studies 14, $28 \mathrm{p}$.

Horton, R. C., 1964a, Hot Springs and sinter deposits, and volcanic cinder cones in Nevada: Nevada Bur. Mines Map 25.

Horton, R. C., 1964b, Geothermal power in Mineral and Water Resources of Nevada, Nevada Bur. Mines Bu11. 65, p. 267-269.

Hunt, T. M., 1970, Net mass 1oss from the Wairakei Geothermal Field. New Zealand: U.N. Symp. on Dev. and Util. of Geothermal Resources, Pisa, Italy.

Imperial County Department of Public Works, 1971, Terms, conditions, standards, and application procedures for initial geothermal development, Imperial County, California. 
James, Russell, 1968, Wairakei and Larderello: geothermal power systems compared, New Zealand Jour. Science 11, p. 706-719.

Jones, P. H., 1970, Geothermal resources of the northern Gulf of Mexico Basin; U. N. Symp. on Dev. and Ut11. of Geothermal Resources, P1sa, Italy.

Kaufman, A., 1970, The economics of geothermal power in the United States: U. N. Symp. on Dev. and Ut1l. of Geothermal Resources, P1sa, Italy.

Kiersch, G. A., 1964, Geothermal steam: Origin, characterist1cs, occurrence and exploitation: U. S. Air Force Cambridge Research Labs. (AFCRL64-898), Washington, D. C., U. S. Dept. of Commerce.

Kilkenney, J. E., 1972, Geothermal Energy, part II, General appraisal of the Earth's prospective energy, in An Inttial Appraisal by the New Energy Forms Task Group, 1971-1985; Other Energy Resources Subconmittee of the National Petroleum Councils Committee on U. S. Energy Outlook, p. $27-35$.

Koenig, J. B., 1967, The Salton-Mexicall geothermal province: Cal1f. Div. Mines and Geol., Mineral Information Service, v. 20, p. 75-81.

, 1969, The Geysers geothermal fleld: California D1v. Mines and Geol., Mineral Inf. Service, v. 22, no. 8, p. 123-128.

, 1970, Geothermal exploration In the western United States: U. N. Symp. on Dev. and Ut1l. of Geothermal Resources, P1sa, Italy. p. $10-12$.

1971, Geothermal development: Geotimes, v. 16, no. 3,

, 1972, The worldwide status of geothermal exploration and development; Trans. Amer. Nuclear Soc. 1972 Annual Mtg., Las Vegas, Nev., June 18-22, 1972, p. 13.

Kruger, Paul, and Otte, C., 1972, Geothermal Energy--Resources, Production, Stimulation, Stanford University Press, Stanford, California, to be published in November, 1972. 
Livingston, V. E., 1972, Overview of yeothermal exploration and development in Washington, present at the Genthermal Resources first

National Conference, El Cen:ro, California.

Mckelvey, V. E., 1972, Mineral Resource Estimates and Public Policy:

American Scientist v. 60, no. 1, Jan/Feb. 1972, p. 32-40.

McNitt, J. R., 1963, Exploration and development of geothermal power in California: Cal. Div. of Mines and Geol. Special Report 75, $45 \mathrm{p}$.

1964, Geology of the Geycers themal area, California:

U.N. Conf. New Sources of Energy, Home, Proc.., v. 2, Geothermid

Energy: I, p. 293-302.

1965, Review of geothemal resources, in Lee, W. H. K., ed., Terrestrial heat flow: Am. Geopiys., Uninn Geophyys. Mon. Ser. no. 8, p. $240-266$.

1970, The geological envioment of geothermal fields as a guide to exploration (Rapporteur's Report): U.N. Symp. on Dev. and Util. of Gethermal Resources, Pisa, Italy.

Mundorff, 1. C., 1970, Major thermal sorings of Utah: Utah Geol. and Minealog. Survey, Water Resources Bull. 13,60 p.

Muffler, L. J. P., and White, D. E., $9 / 2$, Geothermal energy: The Science Teacher, v. 39 , no. 3.

1969, Active metamorphism of upper Cenozoic sediments in the Salton Sea geothemal field and Salton Trough, southeastern California: Geol. Soc. America Bull., v. 80. p. $157-182$.

Muffler, L. J. P., White, D. E., and Truesde11, A. H., 1971, Hydrothermal explosion craters in Yellowstone National Park; Geol. Soc. America Bull., v. 82, no. 3, p. 72.3-740.

Pearl, Richard, 1972, Overview of geothermal exploration and development in Colorado, presented at the Ceothermai Resources First National Conference, El Centro. Califurnia.

Peterson, N. V., and Groh, E. A. 1967, Geothemal potential of the Klamath Fallis area, Oregon--A preliminary study: The Ore Bin, Oregon Dept. of Geol. and Mineral Industries, v. 29, p. 209-231.

Peterson, N. V. and Mcintyre, J. R., 1970, The reconnaissance geology and mineral resources of eastein Kianath County and westem Lake county, Oregon: Oregon Dept. Geol. and Mineral Industries Bull. 66, $70 \mathrm{p}$. 
Reghavan, R., Ramey, H. J, and Kruper, P., 1971, Calculation of Steam Extraction from Nuclear-Explosion Fractured Ceothermal Aquifers, Trans. Am. Nucl. Soc., v. 14, p. 69').

Ramey, H. J., Jr., 1970, Short Time Well Test Data Interpretation in the Presence of Skin Effect and Wellbore Storage, J. Petro. Tech., v. 22, p. 97-104.

Ramey, H. J., Kruger, P., and Raghavan, R., 1972, Stimulation Modes of Geothermal Aquifers, Trans. Am. Nucl. Soc., v. 15, p. 20, see also Kruger and Otte, Editors (1972).

Rex, R. W., 1966, Heat flow in the Imperial Valley of California (abs.): Amer. Geophys. Union Trans., v. 47, p. 181.

1968, Investigation of the geothermal potential of the Lower Colorado River Basin: Phase 1 - The Imperial Valley Project: The Institute of Geophysics and Planetary Physics, University of California at Riverside.

1970, Invest1gation of geothermal resources in the Imperial Valley, and their potential value for desalination of water and electricity production: Riverside, California Univ. Inst. Geophys. and Planetary Phys., 14 p.

1971, Geothermal energy - the neglected energy option: Bull. Atomic Scientists, v. 27, no. 8, p. 52-56.

1972, Geothermal energy, Its potent1al roll in the National energy picture: Riverside, Cal. Univ. Inst. Geophys. and Planetary Phys., Contribution $72-10,8$ p.

Ross, Sylvia H., 1970, Geothermal potential of Idaho: Idaho Bureau of Mines and Geol. Open-file report, $28 \mathrm{p}$.

Roy, R. F.; Decker, E. R., Blackwell, D. D., and Birch, F., 1968, Heat flow in the United States: Jour. Geophys. Research, v. 73, p. 5207-5221.

Sass, J. H., Lachenbruch, A. H., Munroe, R. J., Greene, G. W., and Moses, T. H., Jr., 1971, Heat flow in the western United States: Jour. Geophys. Research, v. 76, no. 26, p. 6376-6413. 


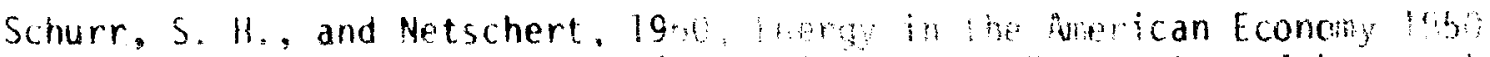
1975: An Economic Study of 1:s is iny and Prospects: Johns hiph ins Press, Baltimore.

Stone, R. T., 1971. Implementing the fderal Geothemal Steam Act of 1970: Northwest Conf. on Geothermal Powr. 15t. Dent. of Natural Resources, 01 ymipia, Washington.

Surmers, W. K., 1965a, A preliminay yort of lew Moxico's geothenal energy resources: New Mexi Mines ard Mineral Resources Circ. $80,41 \mathrm{p}$.

1965b, Chemical charteristics of New Mexico's thennaj waters - a critique: New Men ico Bureau Mines and Mineral Resources; Circ. 83, $27 \mathrm{p}$.

1970a, Geothermal prospects of New Mexico: U. N. Symp. on Dev. and Util. of Geothemal Rescurces, Pisa, Italy.

1970b, New Mexice's themal waters: New Mexico Bur. Mines and Mineral Resources microfim.

phenomena: New Mexico Bur. Mes ad Mineral fesources.

Summers, W. K., and Ross, S. H., 1971, Geothemics in North America: present and future: Wyoming Geol. Assoc. Sarth Sct. Bul1., March, p. $7-22$.

Summers, W. K., 1972, Overview of geothernal exploration and develomult in New Mexico, presented at the Geothermal Resources First National Conference, El Centro, California.

Theobald, P. K., Schweinfurth, 5. P.. and Duncan, O. C., 1972, Energy resources of the United States: i. 3 . Geol. Survey Circ. $650,27 p$.

United Nations, 1924 , United Na ions werence on new sources of energy Proceedings of the conferenct in kome, Italy. Aug. 21-31, 1961, v. 2, ecothemal energy . , A. . ; v. 3, geothermal energy II, $516 \mathrm{p}$.

United Nations, 1970, Report on "ineded Nations Symposium on the Development and Utilization of Geotharmal Resources." Pisa, Italy, Sept. 22Oct. 1,1970 (ST/TAD/Ser.C.:B:

U. S. Dept of Interior. 191, Draft environmental impact statement for the geathermal leasing progran $97 \mathrm{p}$. 
U. S. Dept. of Interior, 1972, Supplement to Draft Environmental Impact Statement for the geothermal Leasing Program, $55 \mathrm{p}$.

U. S. Dept. of Interior, Bureau of Reclamation, 1972, Geothermal Resource Investigations, Imperial Valley, California-Developmental Concepts, $58 \mathrm{p}$.

U. S. Dept. of Interior, Bureau of Reclamation, 1972, Environmental Statement, final deep geothermal test weli, Geothermal Resource Investigation Imperial Valley, Calif., $27 \mathrm{p}$.

Waring, G. A., 1965, Thermal springs of the United States and other countries of the world - a summary: U. S. Geol. Survey Prof. Paper $492,383 \mathrm{p}$.

White, D. E., 1964, Preliminary evaluation of genthermal areas by genchemistry, geology, and shallow drilling: W. N. Bn. of Energy, Rome, 1961, Proc., v. 2, Geothermal Energy: 1, p. 402-408.

1965, Geothermal energy: U.S. Geol. Survey Circ. 519, 17 p.

1968, Hydrology, activity and heat flow of the Steamboat Springs Thermal system, Washoe Co., Nevada: U. S. Geol. Survey Prof. Paper 458-C, 109 p., 53 figs.

1968, Environments of generation of some base-metal deposits: Econ. Geology, v. 63, no. 4, p. 301-335.

1969b, Thermal and mineral waters of the United States a brief review of possible origins: Internat. Geol. Cong., 23rd, Prague 1969, v. 19, p. 269-282.

1970, Geochemistry applied to the discovery, evaluation, and expToitation of geothermal energy resources (Rapporteur's Report): U. N. Symp. on Dev. and Util. of Geothermal Resources, Pisa, Italy.

White, D. E., McNitt, J. R., 1966, Geothermal energy, in Mineral Resources of California, Calif. Div. Mines Geol. Bul1. 191; T74 p.

White, D. E., Muffler, L. J. P., and Truesdell, A. H., 1971, Vapordominated hydrothermal systems compared with hot-water systems:

Econ. Geol., v. 66, p. 75-97.

Whiting, R. L., and Ramey, H. J., Jr. $\frac{1969}{A \text { Application of Material and Energy }}$ Balances to Geothermal Steam Production, J. Petro. Tech. v 21, p. 893900, (1969). 
A National Geothermal Energy Program Budget

The attached program budget and accompanying illustrations were prepared by an interagiency working group composed of representatives from the Geological Survey, the Atomic Energy Commission, the National Science Foundation, the Bureau of Reclamation, the Office of Saline Water, and the Environmental Protection Agency. This group views the program as one involving the cooperative efforts of existing Federal agencies, the university community, and private industry. The Federal government is seen as carrying the major share of the research and development costs until technical and economic feasibilities have been established, at which time industry. will begin to assume the principal costs of the completion of, and production from, specific geothermal systems. Industry would also be involved in earlier phases of the research and development program, but largely on a cooperative and/ or contract basis.

The program and its impact are illustrated in Tables 1,2 , and 3 and Figures $I$ and 2. The separate list of milestones refer to numbered points in Figure 1. "The breakdown followed throughout is that of the 26 June 1972 report entitled Assessment of Geothermal Energy Resources (hereafter referred to as the Peck Report). Table 1 represents the broad budget, by category. Table 2 shows a detailed breakdown of expenditures in the categories of Reservoir Development and Production and Utilization Technology and Economics. The other categories do not lend themselves readily to this type of breakdown, at least with our present state of knowledge. Table 3 presents the range in current estimates of the nation's geothermal energy resources, the probable on-line power capacity resulting from the proposed research and development program, and a first approximation of the effect of the estimated resources on the nation's balance of payments. A simple and inelegant method was used for this last item. The resource was evlauated by comparing it to the cost of another commodity which would produce the same amount of electrical power. The basis was oil, at $68 \phi / \mathrm{MBtu}$, generating at a thermal conversion efficiency of $39 \%$. If coal is used instead of oil, the figures would be reduced by approximately one-third. The geothermal resources were evaluated on the basis of the t.c.e.'s listed in the Peck Report.

The basic premises of the Peck Report were accepted as a starting point in preparing the accompanying budget. The budget figures contained in the Peck Report were subjected to further analysis and discussion, modified accordingly, and extended over the life of a 10-year program (Tables 1 and 2 and Figure 1). The 10-year program includes doing several things that the Peck Report noted es significant and important, but which it regarded as lying beyond the scope of a 5-year program. The results of the extended program are seen as providing a potential power capacity estimated at just under 400,000 megawatts by the year 2000 (Table 3 and Figure 2). The total cost of the research and development needed to realize this capacity is seen to be approximately $\$ 650$ million. 
It should be stressed that these figures, as well as those of the reserve estimates and their equivalent dollar values (Table 3) are not firm figures. The Peck Report ( $p$. 55) lists the various reasons for this, but it is worth re-emphasizing here that the principal basis for uncertainty lies in a lack of factual knowledge about geothermal resources in Eeneral. Compared with some of the other energy resources currently under exploitation by the nation (e.g. oil, gas, and coal), we know. little about U. S. geothermal reserves. The working group essentially views the country's geothermal resources, along with the energy available from oil shale, tar sands, coal gasification, resource conservation and breeder reactors, as intermediate-range energy sources with which to combat the encroaching energy crisis, while we await the evaluation and development of fusion and solar energy sources to meet the national needs. In order to evaluate geothermal energy in the context of all of the other intermediate range options, however, a vigorous program of Federal research is going to have to be initiated.

The assumptions relating the estimated power yield to the research and development costs should be noted here. The Kilkenny estimates and the Psck Report extrapolation were used as a base. All of the GO-NO GO mileposts were assumed to be GO. All of the energy extracted was assumed to be uti.lized in the production of electrical power. The various parts of the program are interdependent. The estimated impact of the various parts of the program were crudely proportioned according to their cost.

The interdependency of the various parts of the program essentially precludes achieving a fraction of the estimated power capacity on-line by expenditure of an equivalent fraction of the estimated total cost. The interdependent nature follows from the dependence of success in one phase of the program on feedback from another and from the common threads which run throughout the program and essentially give it its fabric. This can be illustrated by a single theme like drilling. The development of faster and cheaper drilling techniques is, of necessity, a goal of the Exploration Methods part of the program. Initially, however, conventional drilling techniques will be used, while this work is going on. Drilling is needed in order to put down: 1.) shallow holes for thermal gradient measurements; 2.) holes of intermediate depth" for hear flow measurements; 3.) deeper holes for determining both the three dimensional nature of a given geothermal system and for artificial stimulation and production tests; and 4.) very deep holes for defining the geothermal resources of the deep crust. Thus, the drilling theme runs across the categories of Resource Appraisal and Reservoir Development, as well as Exploration Methods. Development of specific techniques and materials to cope with the extreme environments of natural geothermal systems constitutes part of the Utilization Technology program. The drilling of reinjection wells and the necessity for subsurface monitoring of producing systems brings drilling into the environmental aspects of the total program, as well. Similar arguments can be made for other physical themes such as reinjection, materials development, etc. 
Threads that run across the program fabric in another direction include the various resource types: dry steam, low enthalpy waters, high enthalpy waters, geopressured waters in deep sedimentary basins, hot dry rock, and lava. The working group believes that research on all of these types of systems should go on essentially simultaneously.

A word on the time sequence of various parts of the program is in order. The graphs in Figure 1 show a steady, if irregular, succession of budgetary peaks beginning with Exploration Methods (1976) and running through Resource Appraisal and Utilization Technology (1977), Reservoir Development and Production (1978), Environmental Effects (1979), a second peak in Reservoir Development and Production (1980), and culminating in one in Utilization Technology (1981). The magnitude of these budget peaks and their relative impact creates the waviness seen in the final impact curve (Figure 2). The highest budget peaks represent either massive efforts in development or construction of demonstration power plants and it is our general concensus that at least one such demonstration $9 \mathrm{mut} h \mathrm{~h}$ built for each type of geothermal system. The time-location and varying slopes of the different impact curves reflect varying lags in impact following major $R$ and $D$ efforts and also the fact that the easiest parts of the program are the cheapest and the ones that will be done first. Thus the curves begin to flatten perceptibly toward the year 2000. They do not, however, tend toward zero slopes (relative to the base curve) except in the instances of Exploration Methods and Resources Appraisal, where massive funding will probably begin to yield less and less in terms of return as the year 2000 is approached. 
Mable 1 .

\section{PROPOSED 10-YEAR GEOTHERMAL RESEARCH PROGRAM}

\section{$\$$ in Millions}

II. Exploration Methods

III. Reservoir Development \& Production $1 / 5$

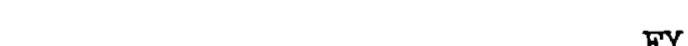

FY

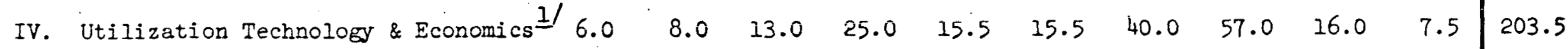

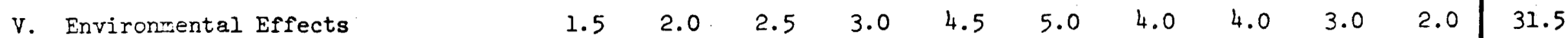

VI. Institutional \& Legal Aspects

TOTALS

\begin{tabular}{rrrrrrrrrr|r}
1974 & 1975 & 1976 & 1977 & 1978 & 1979 & 1980 & 1981 & 1982 & 1983 & Total \\
6.0 & 11.0 & 16.0 & 18.0 & 16.0 & 15.0 & 15.0 & 15.0 & 15.0 & 15.0 & 142.0 \\
5.0 & 8.0 & 11.0 & 9.5 & 6.0 & 3.5 & 2.0 & 1.5 & 1.5 & 1.5 & 49.5 \\
$1 / 1.0$ & 13.5 & 27.0 & 44.0 & 48.0 & 21.5 & 23.0 & 13.0 & 10.5 & 10.0 & 215.5 \\
16.0 & 8.0 & 13.0 & 25.0 & 15.5 & 15.5 & 40.0 & 57.0 & 16.0 & 7.5 & 203.5 \\
1.5 & 2.0 & 2.5 & 3.0 & 4.5 & 5.0 & 4.0 & 4.0 & 3.0 & 2.0 & 31.5 \\
1.5 & 2.0 & 1.5 & 1.5 & 1.5 & 0.5 & 0.5 & 0.5 & 0.5 & 0.5 & 10.5 \\
\hline 25.0 & 44.5 & 71.0 & 101.0 & 91.5 & 61.0 & 84.5 & 91.0 & 46.5 & 36.5 & 652.5
\end{tabular}

I/ For detailed breakdown by resource type, see Table 2. 
Table 2.

DE IAIIES EPEAKDOWN OF PROGRAM CATEGORIES III AND IV BY RESOURCE TYPE

$\$$ in millions

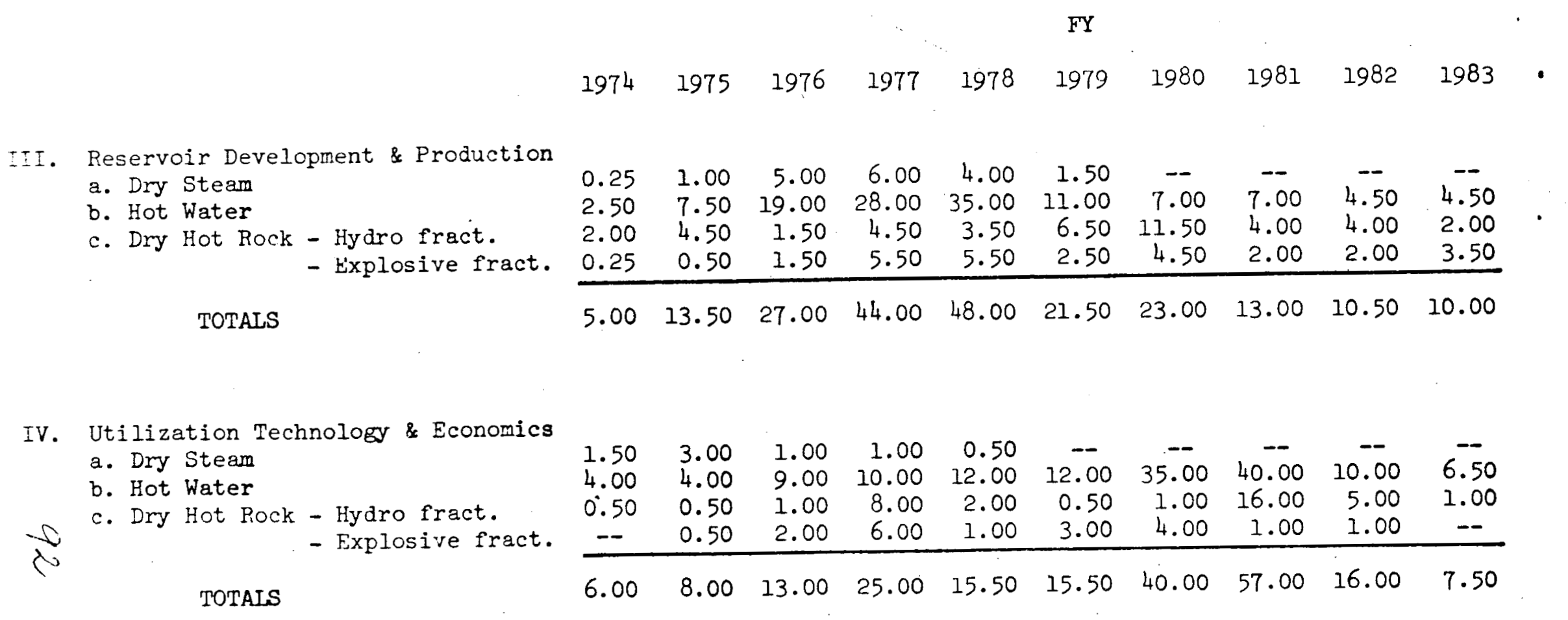


Table 3.

Geothermal Resources, Potential Power Installed, and Resource Values

$\begin{array}{llllll}1975 & 1980 & 1985 & 1990 & 1995 & 2000\end{array}$

A. Range of estimated cumulative geothermal energy resources available in thousands of megawat centuries (low figures are based on estimates by D. E. White and I. J. P. Muffler; bigh figures are those of R. W. Rex.)

B. Potential power installed resulting from program, in thousands of megawatts.

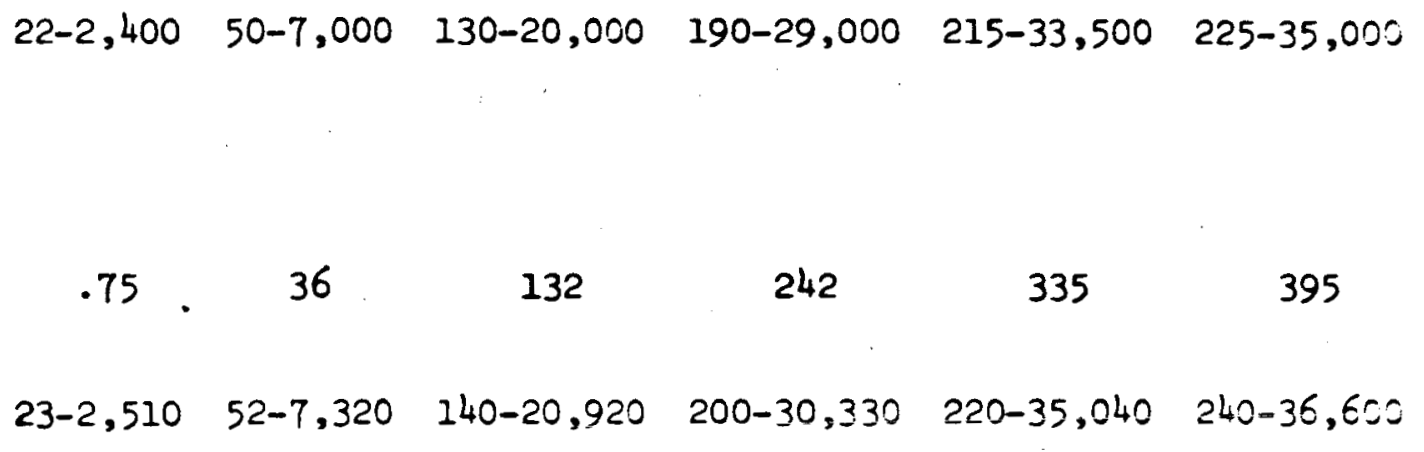

c. Value of estimated resource as dollar equivalents of electrical power generated from imported oil, in billions of dollars. 


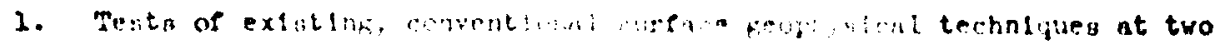

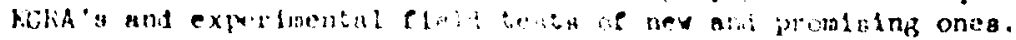

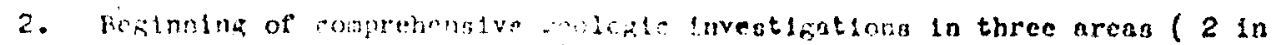
Calleornin and one in Magka)

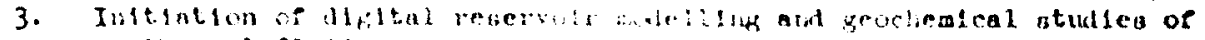
Geotherming plulik.

4. Initintion of Intenalve hett-fi.. in:iling propisin (boles of moderated (lepth).

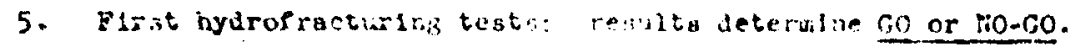

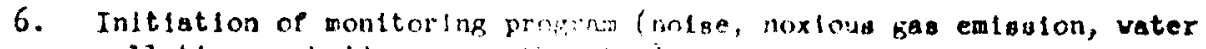
pollution, subsidence, eartintisia).

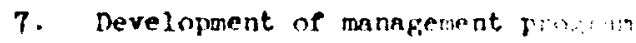

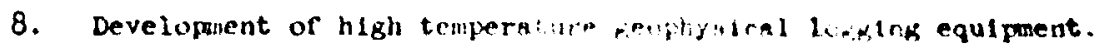

9. Denonstration of prototype semerating piant for bot dry rock.

10. Binary cycle tests conpleted for bot water nystems.

11. Preparation of molel code n!u! enimishinent of centralized Federal information facility.

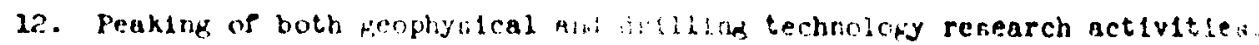

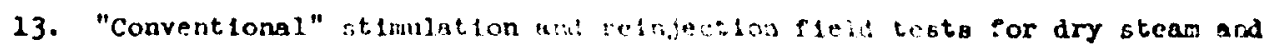
icio waver aygiews.

14. Development of recovery tect:i! :" for minerals nod gaces in solution in geotherwal elulda.

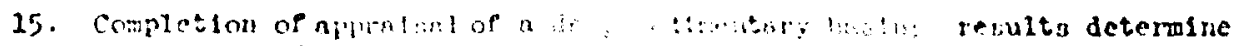

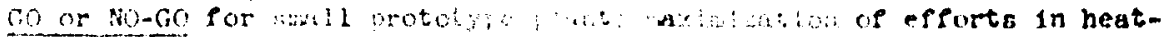

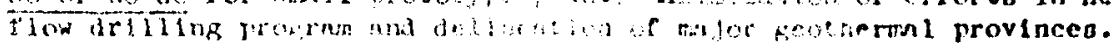

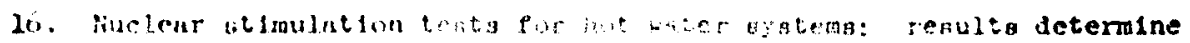

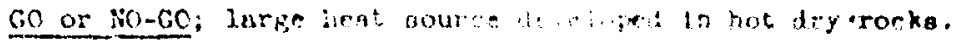

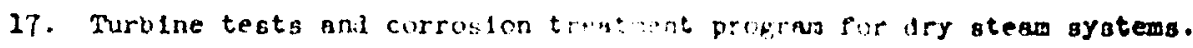

18. Developwent of a1r pollution nul : lan control nystems.

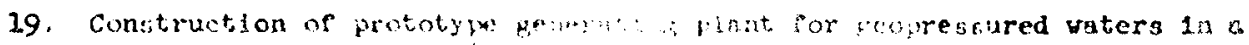

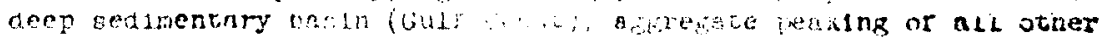
development a mid minlaction resing:i.

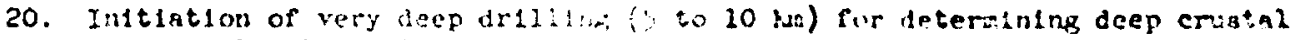
fectheral potentin?.

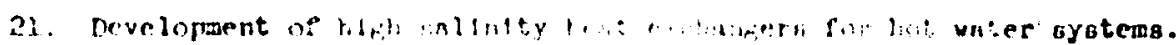

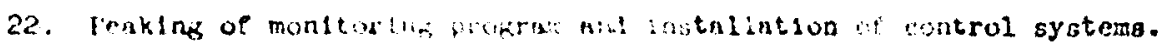

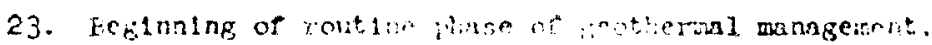

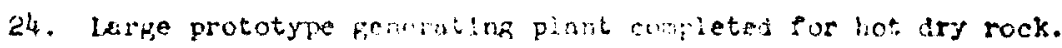

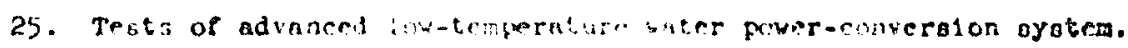

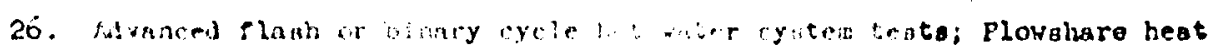

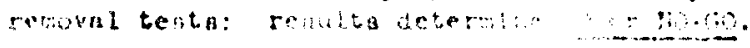

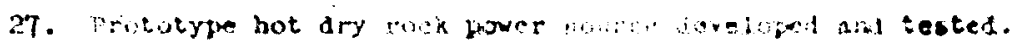

